\title{
Connector Well Experiment to Recharge the Floridan Aquifer, East Orange County, Florida
}

\section{United States Geological Survey Water-Supply Paper 2210}

\section{Prepared in}

cooperation with the South Florida Water Management District, Tallahassee, Florida

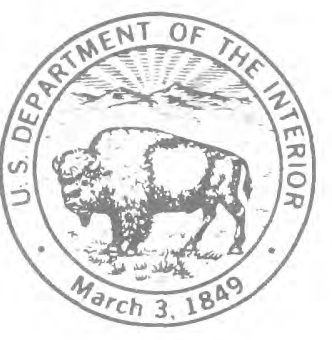




\title{
Connector Well Experiment to Recharge the Floridan Aquifer, East Orange County, Florida
}

\author{
By P. W. BUSH
}

Prepared in cooperation with the South Florida Water Management District, Tallahassee, Florida 


\section{UNITED STATES DEPARTMENT OF THE INTERIOR}

JAMES G. WATT, Secretary

GEOLOGICAL SURVEY

Dallas L. Peck, Director

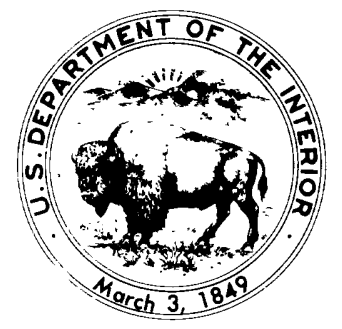

For sale by Distribution Branch

Text Products Section

U.S. Geological Survey

604 South Pickett Street

Alexandria, Virginia 22304

Library of Congress catalog-card No. 83-600510 


\title{
CONTENTS
}

\author{
Abstract 1 \\ Introduction 1 \\ Hydrologic setting 2 \\ Hydrology 2 \\ Geohydrology 2 \\ Site selection and description 4 \\ Connector well design 4 \\ Measurement of connector well flow 10 \\ Water-level monitoring 13 \\ Results of experiment 15 \\ Connector well performance 15 \\ Water-level response 15 \\ Analysis of results 15 \\ Conclusions 23 \\ References 25
}

\section{FIGURES}

1. Map showing location of connector well site, east Orange County, Florida 3

2. Map showing topography in area of connector well site $\mathbf{5}$

3. Lithologic log of shallow aquifer and confining layer at connector well site 6

4. Grain-size distribution curves for site of well $82911001 \quad \mathbf{7 - 8}$

5. Sketch showing connector well installation 9

6. Grain-size distribution curve of filter-pack material 10

7. Sketch showing orifice plate-packer assembly $\mathbf{1 1}$

8. Sketch showing orifice plate-packer assembly positioned in connector well 12

9. Graph showing head-versus-discharge rating curve for 1.125 -inch orifice 13

10. Sketch showing plan view of observation well network at connector well site 14

11. Hydrographs of wells 82811103,82911102 , and 82911101 , for periods before and after opening connector well 16

12. Graphs showing water levels in observation wells of south line before and after opening connector well 17

13. Graphs showing water levels in wells at three different depths 10 months after opening connector well 18

14. Graph showing gamma gamma density log, well 17, August 25, 197619

15. Graph showing neutron porosity log, well 17, August 25, 197620

16. Sketch showing equipotential diagram in shallow aquifer before and after opening connector well $\mathbf{2 1}$

17. Sketch showing flow lines in shallow aquifer superimposed on equipotential lines of figure 1622

18. Graph showing logarithmic distance-drawdown plot of water-level data superimposed on leaky-aquifer type curve $\mathbf{2 4}$

\section{TABLE}

1. Summary of results of type-curve solutions and related calculations 25 


\title{
Connector Well Experiment to Recharge the Floridan Aquifer, East Orange County, Florida
}

\author{
By P. W. Bush
}

\begin{abstract}
An experimental connector well, screened in the shallow sand aquifer, finished with open hole in the Floridan aquifer and cased through the confining layer between the two aquifers, was drilled in east Orange County, Fla., to obtain information on the nature and function of the shallow aquifer as related to connector well operation. The potentiometric surface of the shallow aquifer is about 45 feet higher than the potentiometric surface of the Floridan aquifer; hence water flows by gravity from the shallow aquifer to the Floridan aquifer through the well "connecting" the two aquifers. Continuous flow measurement over 10 months shows the well discharge varies seasonally and averages slightly more than 50 gallons per minute. Observation wells show that, except for seasonal variation, water levels within the area of influence have reached steady state within measurable limits. Vertical anisotropy in the shallow aquifer is apparently caused by the shape and (or) arrangement of the sand grains that comprise the shallow aquifer, rather than because of distinct confining layers of different lithology. Transmissivity of the shallow aquifer at the site is about 600 square feet per day. Extensive dewatering of wetlands in east Orange County by connector wells alone probably is not feasible. Nevertheless, large amounts of water could be channeled to the Floridan aquifer by connector wells. The results of the connector well experiment imply that water is being captured from evapotranspiration and interception of water that would have discharged to swamps in the vicinity of the connector well. However, the data available from this experiment do not permit a quantitative expression of the net gain in recharge to the Floridan aquifer resulting from operation of the connector well.
\end{abstract}

\section{INTRODUCTION}

This study, begun in 1973 in cooperation with the then Central and Southern Florida Flood Control District (now South Florida Water Management District), was the outgrowth of an earlier study by Knochenmus (1975) to determine the technical feasibility of artificially recharging the Floridan aquifer in east Orange County. Knochenmus (1975) analyzed the geohydrologic conditions in the area and concluded that artificial recharge was technically fea- sible and could be accomplished by a network of connector wells. The connector wells would be screened in the shallow aquifer, finished with open hole in the Floridan aquifer, and cased through the confining layer between the two aquifers. Because the potentiometric surface of the shallow aquifer (water table) is higher than the potentiometric surface of the Floridan aquifer, water would flow from the shallow aquifer to the Floridan aquifer through wells "connecting" the two aquifers. Removal of water from the shallow aquifer would lower the average water-table elevation and thereby reduce water losses to evapotranspiration and runoff. The water "captured" from these sources thus would be the source of supply for the artificial recharge

According to Knochenmus (1975, p. 24) the number of wells per unit area and the well spacing needed to lower the water table enough to make such a project practicable depend on the transmissivity of the shallow aquifer, the rate of capture, and the "available drawdown" in the wells. The available drawdown in a well is that part of the potential drawdown that can be achieved at a given site. Potential drawdown depends on the position of the water table relative to the potentiometric surface of the Floridan aquifer and on the position of that potentiometric surface relative to the well screen. When the potentiometric surface of the Floridan aquifer is above the bottom of the screen, potential drawdown equals the difference in head between the two aquifers. When the potentiometric surface of the Floridan is below the bottom of the screen, the potential drawdown is the difference between the altitude of the water table and the altitude of the bottom of the screen. The rate of capture is a function of the depth to the water table below land surface. Knochenmus further assumes that, after withdrawal begins and as the depth to water increases, the capture rate increases until some maximum rate is attained, at which point more drawdown will not affect the capture rate. He presents the results of numerical analyses to determine the optimum well spacing, discharge per well, and number of wells per square mile for fully penetrating wells with negligible head losses for various combinations of hydrologic conditions. His analyses consider only capture from evapotranspiration and not from interception of water that would otherwise 
have discharged to surface-water bodies. Optimum in this instance means spacing such that the depth to water at saddle points on the stressed water table (points where drawdown is minimum) will be the depth at which the capture rate becomes maximum and further drawdown will not increase capture. The analyses are based on an assumed shape of the capture-drawdown function, on estimates of maximum capture rate and the depth at which it occurs, and on estimates of shallow aquifer transmissivity.

The primary objectives of this study, at its inception, were to design and construct a connector well in east Orange County and to conduct field experiments to define the capture-drawdown function. The secondary objectives were to determine the transmissivity of the shallow aquifer and to collect other information that would contribute to understanding the nature and function of the shallow aquifer as related to connector well operation; in other words, to verify the critical parameters that had to be estimated in Knochenmus' study.

Concurrent with design and construction of the connector well, members of the U.S. Geological Survey research staff assisted in developing a field experiment that would provide a relation between capture and drawdown. M. I. Rorabaugh (oral commun., March 1975), one of the members of this staff, concluded that the capture-drawdown function in east Orange County could not be defined with any degree of confidence from aquifer response to a single connector well. Rorabaugh compared specific capacities of hypothetical wells discharging from aquifers where (1) no capture occurred and (2) capture from evapotranspiration occurred, and he obtained differences so small that they probably could not be measured for drawdown distributions considered realistic. According to Rorabaugh, meaningful capture-drawdown data possibly might be obtained with a minimum network of nine connector wells; however, installing eight additional connector wells was not a practical consideration. Thus, one of the primary project objectives was not met.

This report documents the design of the connector well, its performance over a 10 -month period, and information on the shallow aquifer in east Orange County gained through operation of the connector well.

\section{HYDROLOGIC SETTING}

\section{Hydrology}

The hydrologic system of east Orange County is described in detail by Knochenmus (1975). Figure 1 shows the approximately 300 square miles included in his study. The area is predominantly flat, ranging in altitude from about 8 feet to just over 90 feet. It has a high water table, generally within 5 feet of land surface, which results in very wet and swampy conditions.
Knochenmus estimated average annual rainfall in east Orange County to be about 55 inches. More than 70 percent of this water is believed lost to evapotranspiration. Anderson (Lichtler and others, 1968) estimated runoff for the Econlockhatchee and Little Econlockhatchee River basins to be 10 inches per year. Evapotranspiration is highest and runoff lowest near basin divides where drainage is poorly developed. Natural recharge to the Floridan aquifer is estimated by Knochenmus to average less than 2 inches per year.

Surface water in the area is generally soft (hardness less than 60 milligrams per liter), slightly acidic, noticeably colored, and low in dissolved solids (generally less than 150 milligrams per liter). Water in the shallow aquifer is similar except that it is harder, contains more dissolved solids, and has less color. Water in the upper part of the Floridan aquifer contains still more dissolved solids than does water in the shallow aquifer. In the western part of Knochenmus' study area, dissolved-solids concentration of water in the Floridan aquifer is 200 milligrams per liter. The quality of Floridan aquifer water becomes poorer toward the east, reaching a dissolved-solids concentration of about 2,000 milligrams per liter near the St. Johns River.

\section{Geohydrology}

The uppermost geohydrologic unit, the shallow aquifer, is 40 to 80 feet thick throughout the area. Fine sand occurs near land surface; it becomes finer and slightly clayey with depth. Shell beds are common in the lower part of the shallow aquifer.

Where the aquifer material becomes predominantly clay, it is considered part of the 60 - to 300 -foot-thick confining layer that separates the shallow aquifer from the Floridan aquifer. Sand and shell are intermixed with the clay in the confining layer. Where these materials occur as distinct layers, they have the potential to yield water to wells and are considered secondary artesian aquifers.

Beneath the confining layer, and 100 to 350 feet below land surface, is the limestone of the Floridan aquifer. It is thick and highly permeable and is the principal water-bearing stratum in central Florida. Large wells may yield as much as 4,000 gallons per minute (Lichtler and others, 1968, p. 95). In east Orange County, the altitude of the potentiometric surface of the Floridan aquifer ranges from about 45 feet above mean sea level near Union Park to about 20 feet above mean sea level near the St. Johns River. Its range of fluctuation is about 10 feet, approximately twice the range of fluctuation of the water table of the shallow aquifer. In some parts of east Orange County, the difference in head between the water table and potentiometric surface of the Floridan aquifer averages more than 40 feet. 


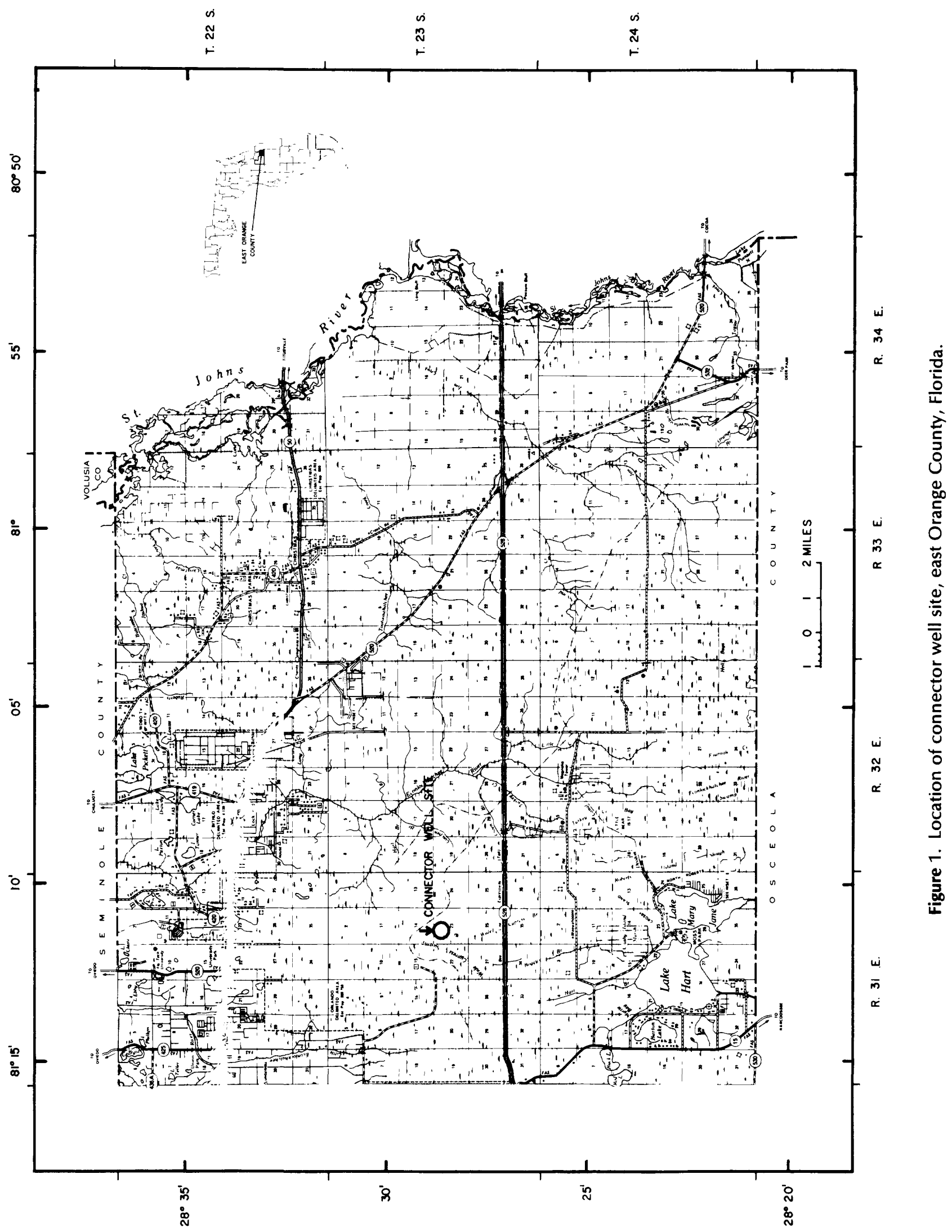




\section{SITE SELECTION AND DESCRIPTION}

In selecting a connector well site, the intent was to choose one that offered the best possible conditions for connector well operation and testing and one that would remain isolated from encroaching development for several years. The best aquifer conditions for connector well operation are high transmissivity in the shallow aquifer and a large head difference between the water table and potentiometric surface of the Floridan aquifer.

The connector well site was selected on the basis of Knochenmus' work in the area. He drilled 12 core holes into the confining layer to provide sample coverage of the shallow aquifer in east Orange County. Sites with little or no clay in the first 30 to 50 feet of material were assumed to have higher transmissivities than those with clay. The site selected is in $\mathrm{N} 1 / 2$ sec. 23, T. $23 \mathrm{~S}$., R. $31 \mathrm{E}$. and is numbered 82811102 on figure 2 . This number is applied also to the connector well itself. At the connector well site, the shallow aquifer is composed of sand, and the difference in head between the water table and the potentiometric surface of the Floridan aquifer is more than 40 feet. The connector well site in section 23 was selected on relatively high ground to assure access to the wells during wet seasons (fig. 2). Palmettos are the most common plant type at the site, and slash pine and longleaf pine abound. The unstressed water table at the site during 1975 ranged from about 2 to 6 feet below land surface. The site is fairly flat; there is an upward land-surface gradient of 0.0045 foot per foot to the north from the connector well, an upward gradient of 0.0050 foot per foot to the east, a downward gradient of 0.0050 foot per foot to the south, and a downward gradient of 0.0075 foot per foot to the west. The unstressed water table also slopes west-southwest with a maximum gradient, in that direction, of 0.0050 foot per foot. The potentiometric surface of the Floridan aquifer at the site during 1975 ranged from about 46 to 53 feet below land surface. Thus, the natural head difference at the site was approximately between 44 and 47 feet.

Before drilling the well, a core hole was drilled at the site to determine the depth and composition of the shallow aquifer and the depth to the top of the rock of the Floridan aquifer. This information was necessary to select the screened interval, size of screen slot, length of screen, and size of filter pack. Split-spoon samples taken at 5-foot intervals showed that the shallow aquifer is about 40 feet thick and consists of sand (fig. 3). At a depth of about 40 feet, the material becomes clayey, indicating the beginning of the confining layer. Silty or clayey sand is the most prevalent material for the next 100 feet. The material becomes less sandy with depth, and, at about 143 feet, it becomes mostly clay. Near the top of the rock, which occurs at a depth of 196 feet, the material is tight sticky green clay, typical of relatively impermeable confining layers in central Florida.
Grain-size distribution curves of shallow aquifer samples (fig. 4) show that the material is mostly fine sand and very uniform. Comparison with grain-size analyses of the samples from Knochenmus' nearby test hole (well 82911001 , fig. 2) indicates that, areally, the shallow aquifer material is similar, at least in the vicinity of the two wells. However, the top of the confining layer is at a slightly shallower depth at well 82911001 than at the connector well site, as implied in figure $4 D$.

\section{CONNECTOR WELL DESIGN}

Information from the core hole at the connector well site in section 23 indicates the base of the shallow aquifer is about 40 feet below land surface and the top of the limestone of the Floridan aquifer is at about 196 feet. The 8 -inch connector well (fig. 5) is cased to 198 feet with 28 feet of screen at depth 10 to 38 feet. The well was installed by cable tool method. It was planned to seat the casing at depth 200 feet ( 4 feet into rock) so the screen would be at depth 12 to 40 feet, but the casing could not be driven past 198 feet. The well was drilled open-hole 98 feet into the Floridan aquifer, from 198 to 296 feet.

A 6-inch-thick filter pack was set around the screen to increase the effective diameter $(D)$ of the well to 20 inches. Criteria used for selection of filter pack size and screen size are as follows (Johnson and others, 1966, p. H30):

(1) Thickness of filter pack $>3$ inches;

(2) $D_{30}$ filter pack $\geq 4$ times ( $D_{30}$ aquifer) and $<6$ times $\left(D_{30}\right.$ aquifer); and

(3) Screen opening $\geq D_{10}$ filter pack where $D_{30}=$ particle diameter corresponding to 30 percent finer and $D_{10}=$ particle diameter corresponding to 10 percent finer.

From figure 4 , the average $D_{30}$ of the shallow aquifer material is 0.16 millimeter. Thus,

0.64 millimeter $\geq D_{30}$ filter pack $<0.96$ millimeter.

Figure 6, a grain-size distribution curve of the filter pack material, shows the 30 -percent finer size to be within the prescribed size range.

The screened sections of the well are stainless-steel wrapped perforated pipe with a slot size of 0.012 inch. The filter pack size is selected to retain most of the aquifer material, and the screen slot size is selected to retain most of the filter pack material. Figure 6 shows that the screen slot size could have been somewhat larger and still met the design criteria.

One or more layers of sand or sand and shells that occur in the confining layer could have been screened in addition to the sandy material in the shallow aquifer. This would provide more recharge to the Floridan aquifer, but additional screen(s) in the sand and shells (a secondary artesian aquifer) would not have provided data to help 


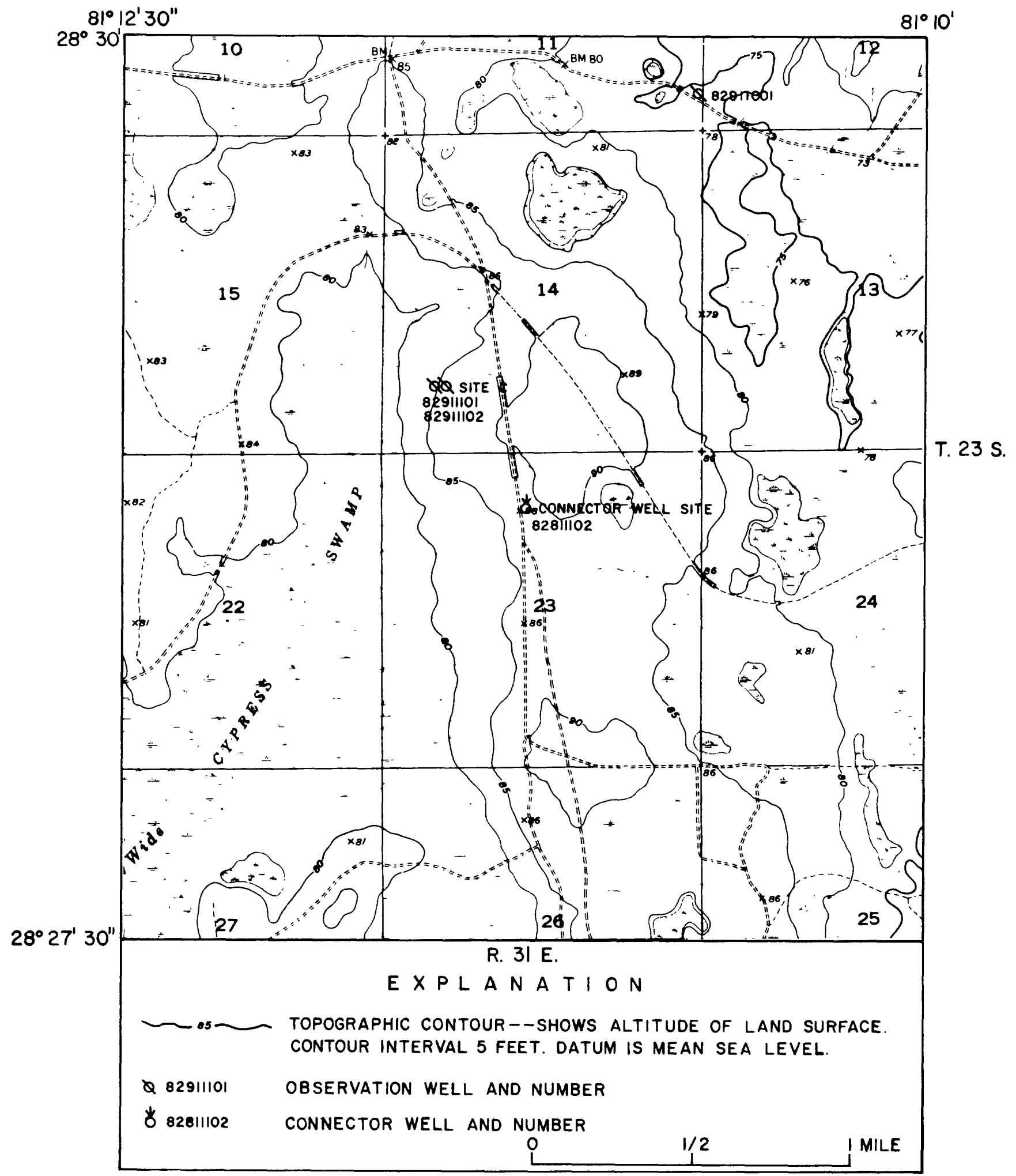

Figure 2. Topography in area of connector well site. 


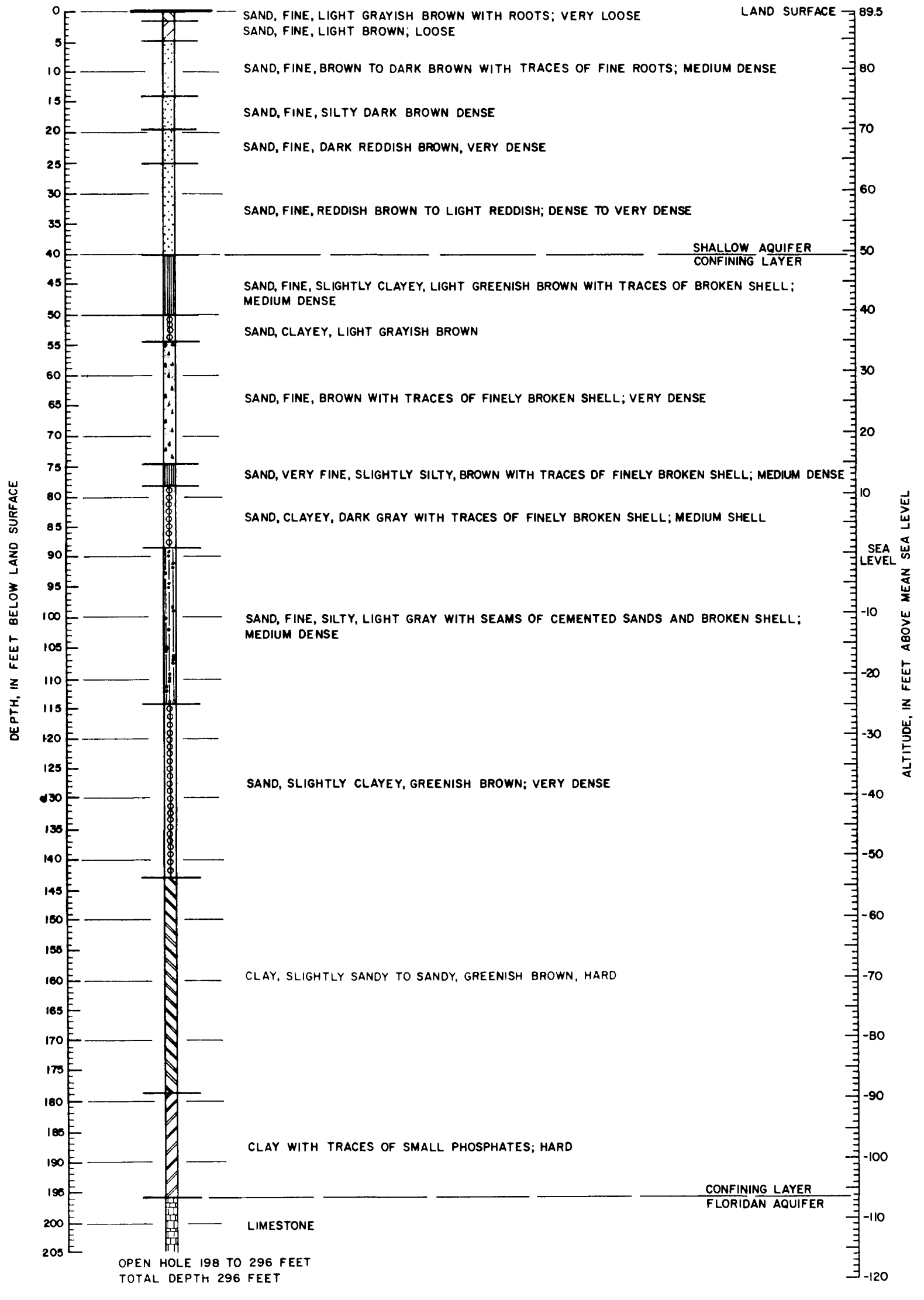

Figure 3. Lithologic log of shallow aquifer and confining layer at connector well site.

\section{Connector well experiment, Florida}




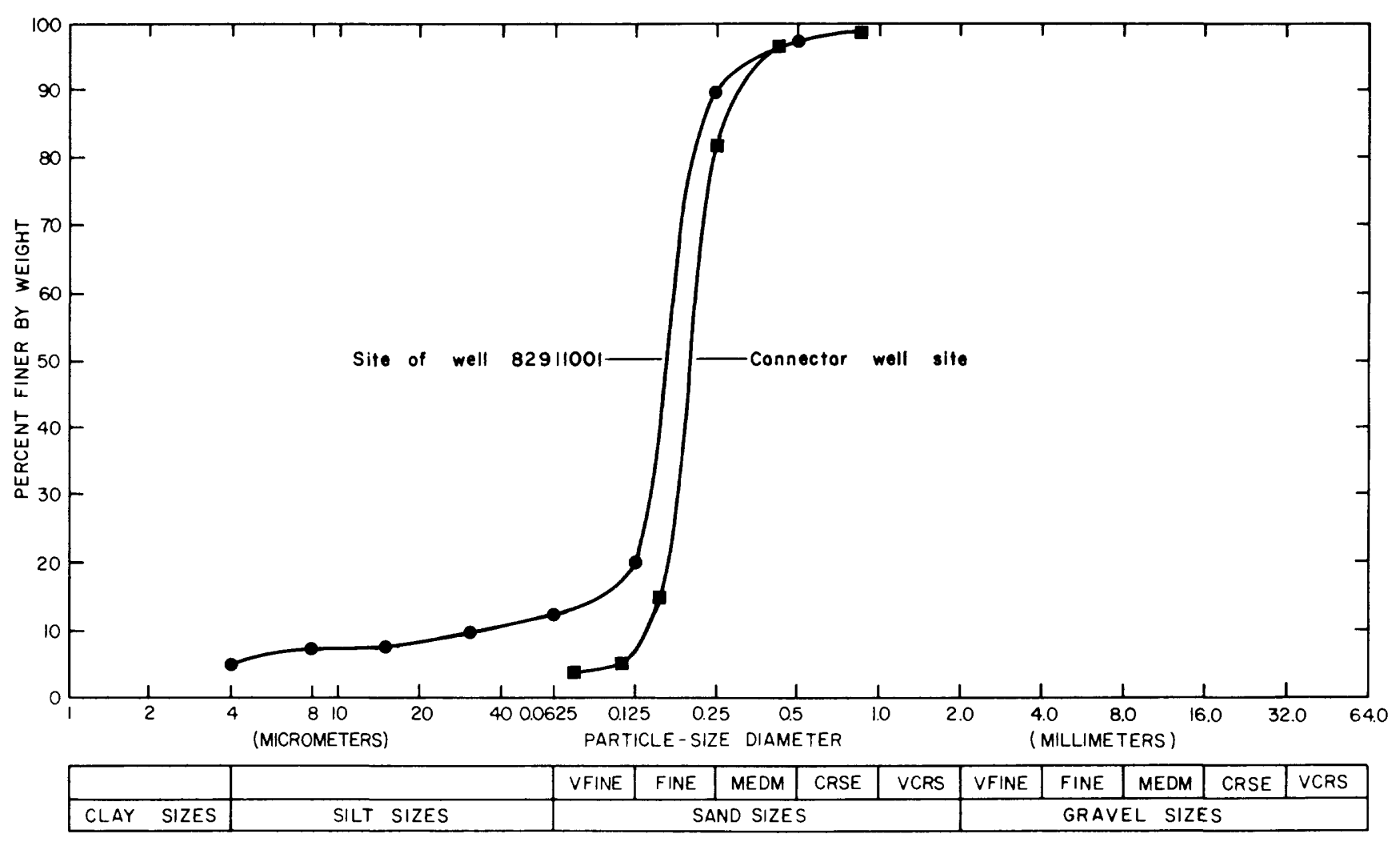

Figure 4. A, Grain-size distribution curves for site of well 82911001 at depth 7 to 8 feet and for connector well site at depth 4.5 to 6 feet.

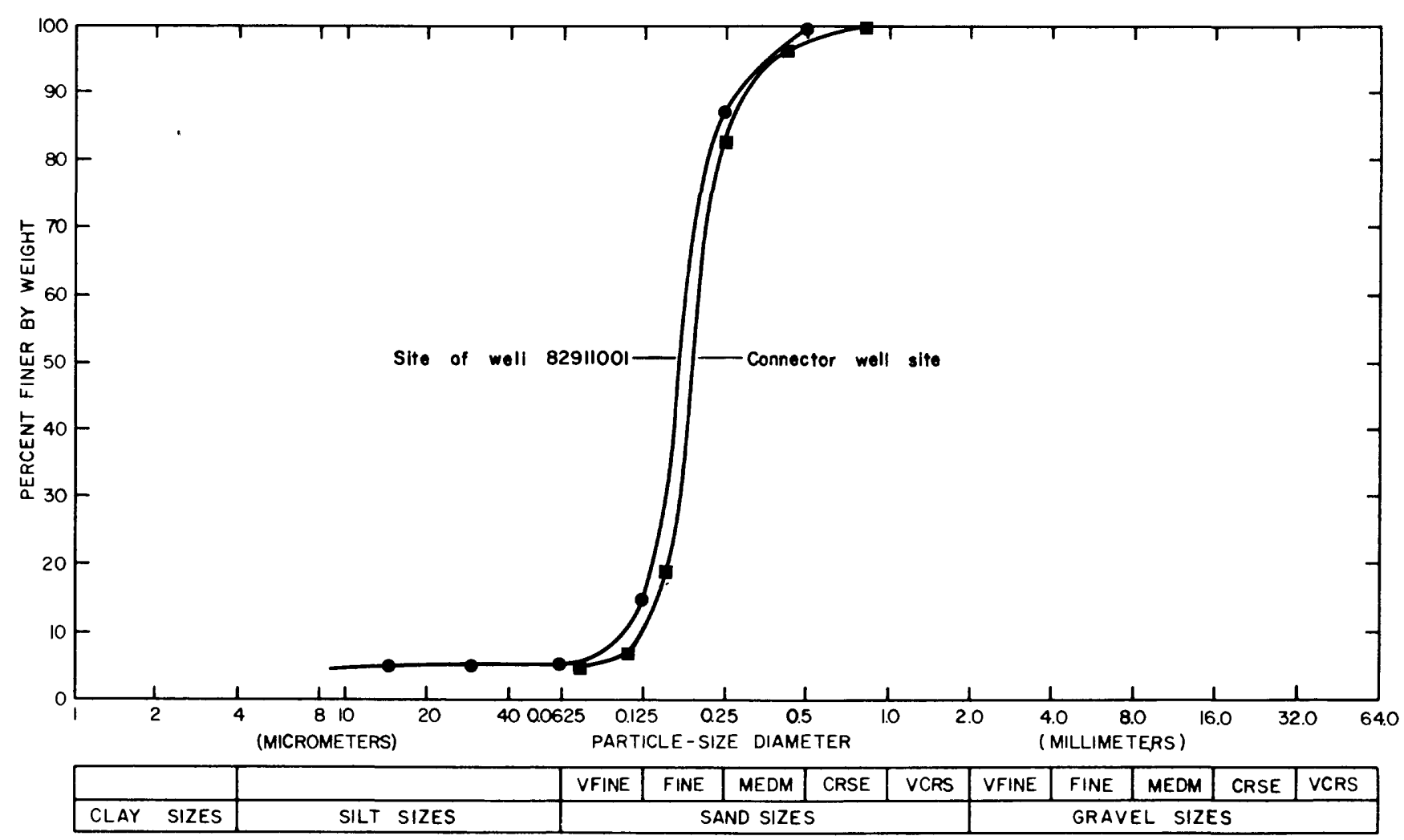

Figure 4-Continued. B, Grain-size distribution curves for site of well 82911001 at depth 17 to 18 feet and for connector well site at depth 19.5 to 21 feet. 


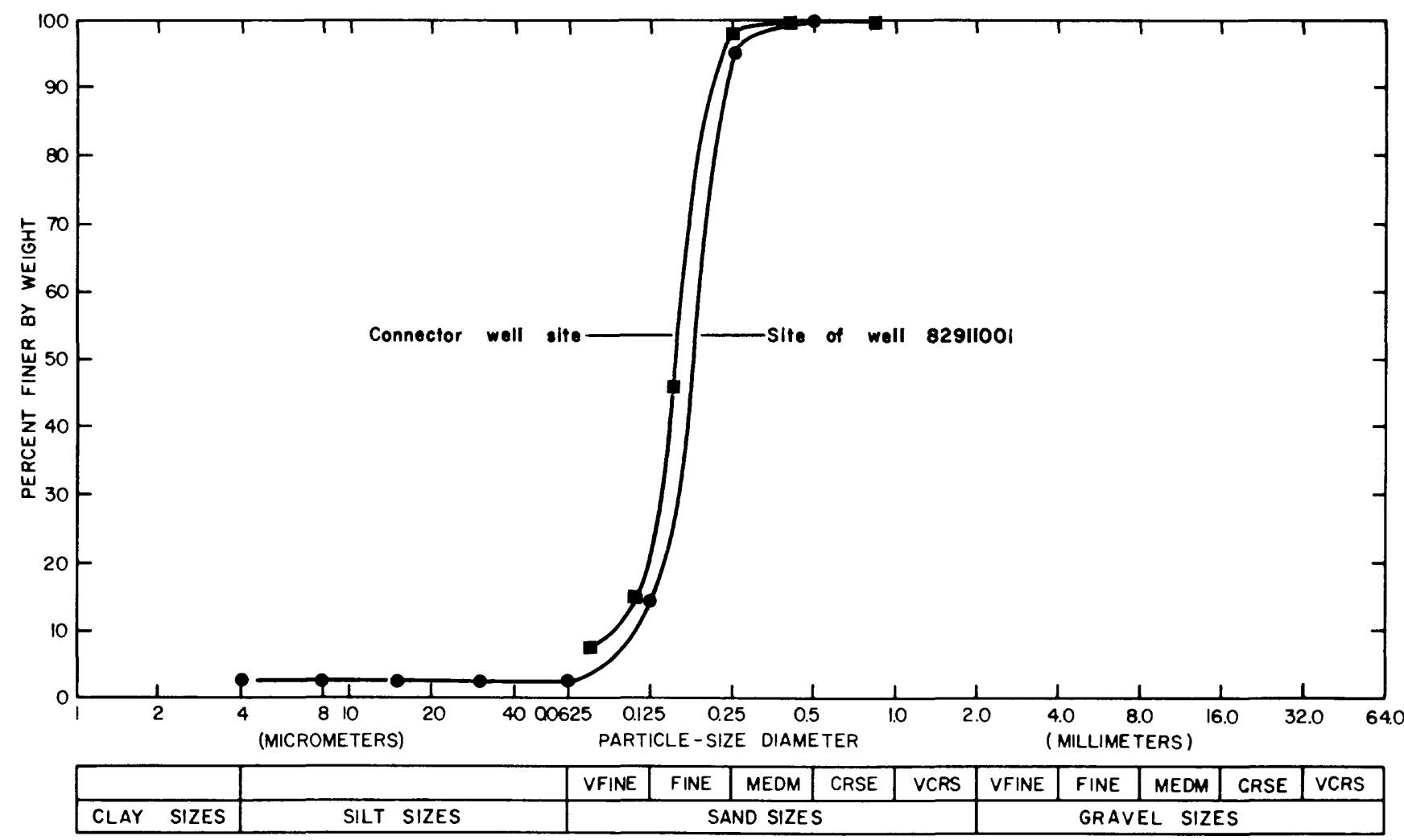

Figure 4-Continued. $C$, Grain-size distribution curves for site of well 82911001 at depth 22 to 28 feet and for connector well site at depth 29.5 to 31 feet.

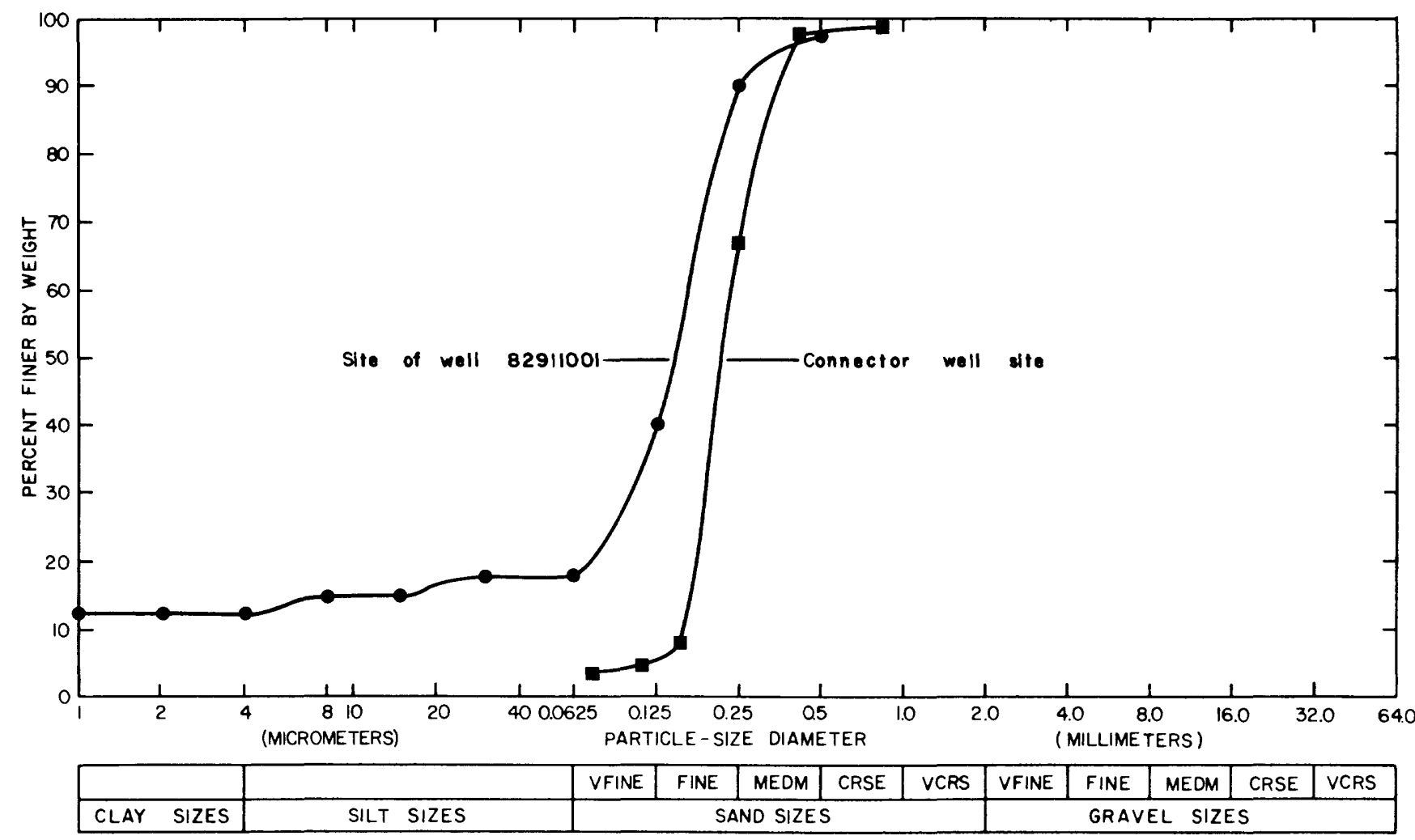

Figure 4-Continued. $D$, Grain-size distribution curves for site of well 82911001 at depth 37 to 38 feet and for connector well site at depth 34.5 to 36 feet.

\section{Connector well experiment, Florida}




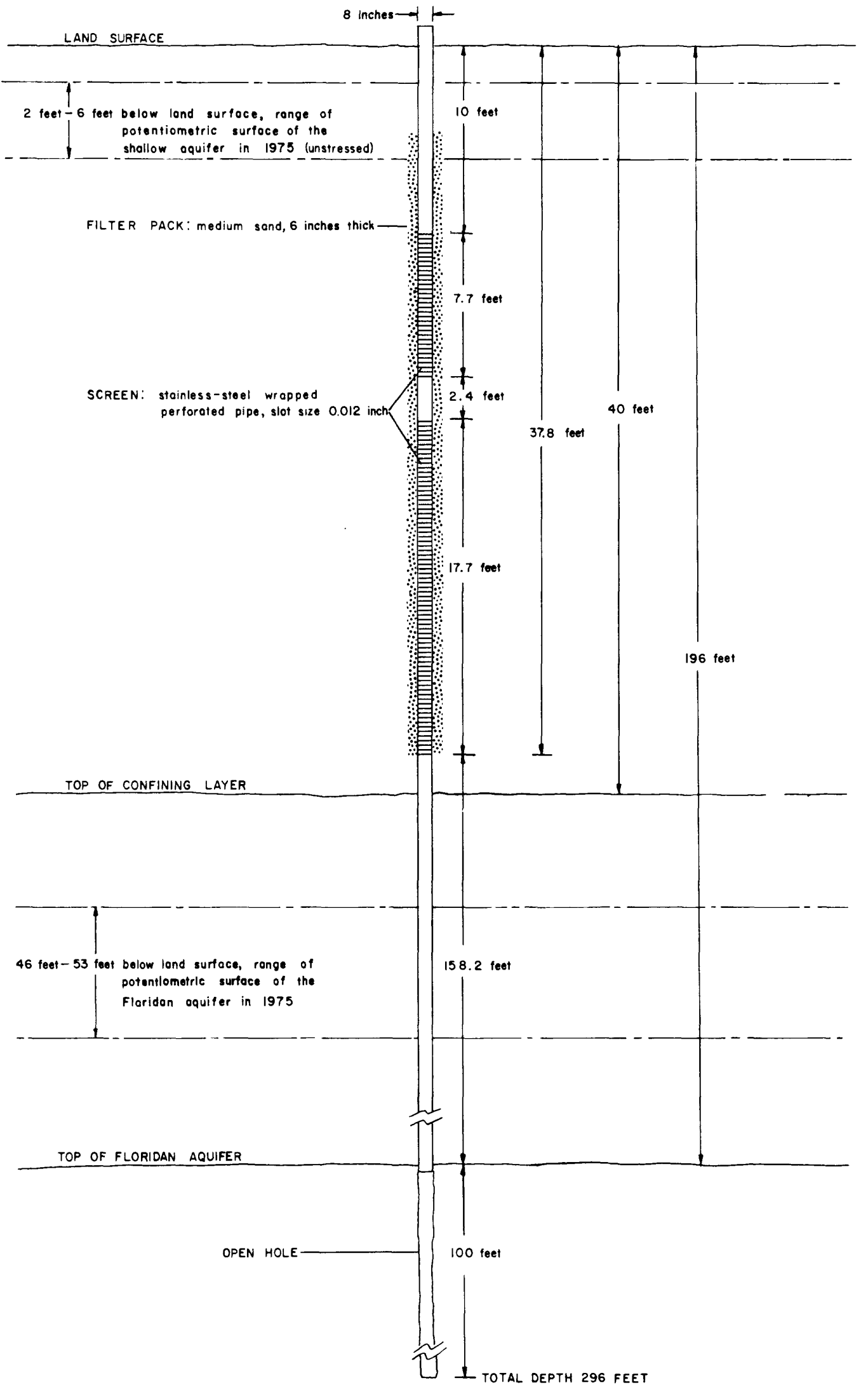

Figure 5. Connector well installation.

Connector well design 9 
evaluate capture, the primary objective at the time the well was designed.

It was not known prior to well construction, and still is not known, to what extent the filter pack increases flow into the well. Although the means to measure capture as a function of drawdown was not known at the time of well design, it was thought that maximum stress on the shallow aquifer would be helpful; hence every practical measure to maximize drawdown in the shallow aquifer was taken.

\section{MEASUREMENT OF CONNECTOR WELL FLOW}

Accurate and continuous measurement of flow in the well is needed to analyze capture, determine aquifer parameters, and judge the performance of the well with time. To measure flow in the connector well, a device using an orifice plate as a control was installed. The principle of its operation is similar to that of a stage-discharge station in that head above the control is measured and a head-versus-discharge rating curve is used to obtain discharge through the orifice.

The 0.06-inch-thick stainless-steel orifice plate sits atop a 6-inch-diameter PVC sleeve positioned in the well below the screen and above the potentiometric surface of the Floridan aquifer. An oxygen-inflated packer made from a small tire tube blocks the annular space between the outside of the 6-inch-diameter sleeve and the inside of the 8-inch-diameter well casing, thus channeling all the discharge through the orifice. Constant pressure is maintained in the inflated packer by a regulator on an oxygen tank connected to the packer by a 0.12 -inch-diameter air line. Constriction of flow by the orifice causes buildup of a column of water above the plate. The weight of the column of water and orifice plate-packer assembly is supported by chains connecting the device to the top of the well casing. Figures 7 and 8 show details of the orifice plate-packer assembly and the device positioned in the well. The height of the column of water on the plate is measured continuously by a water-level recorder.

Discharge through the orifice (well discharge) is directly proportional to the square root of the head on the orifice plate. The orifice flow equation is:

$$
Q=448.83\left(C_{d} A_{o} \sqrt{2} g\right)(\bar{H})
$$

where $Q$ is the discharge, in gallons per minute;

$C_{d}$ is a discharge coefficient (dimensionless);

$A_{O}$ is the area of the orifice, in square feet;

$g$ is the acceleration due to gravity, 32.2 feet per second per second; and

$H$ is the head above the orifice plate, in feet. The product, $C_{d} A_{O} \sqrt{2 g}$, was obtained by experiment, as follows. The orifice plate-packer assembly was placed in

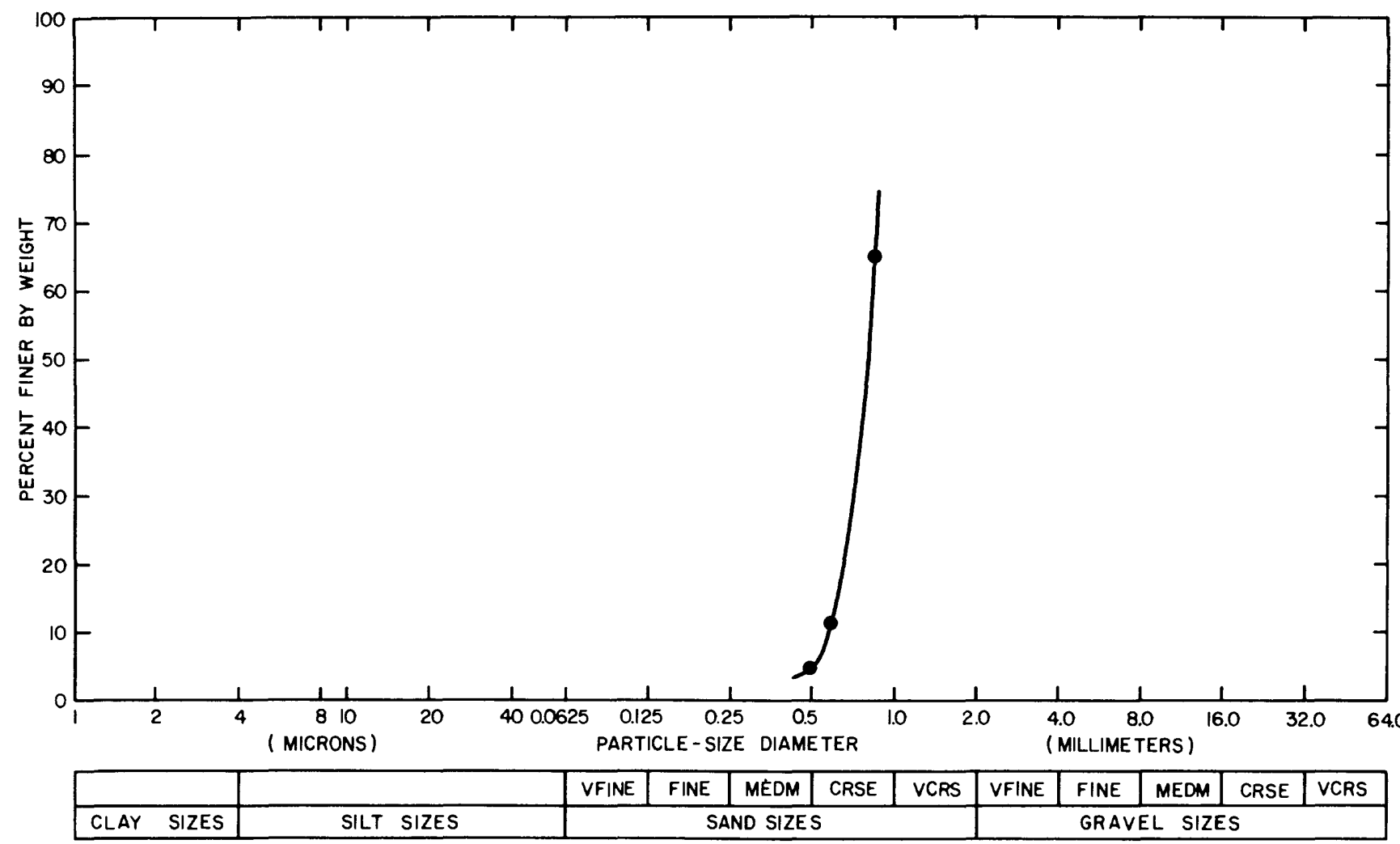

Figure 6. Grain-size distribution curve of filter-pack material. 
8-in-diameter connector well cosing 1/8-in-diameter air line connecting inflated tube to compressed oxygen tank and regulator

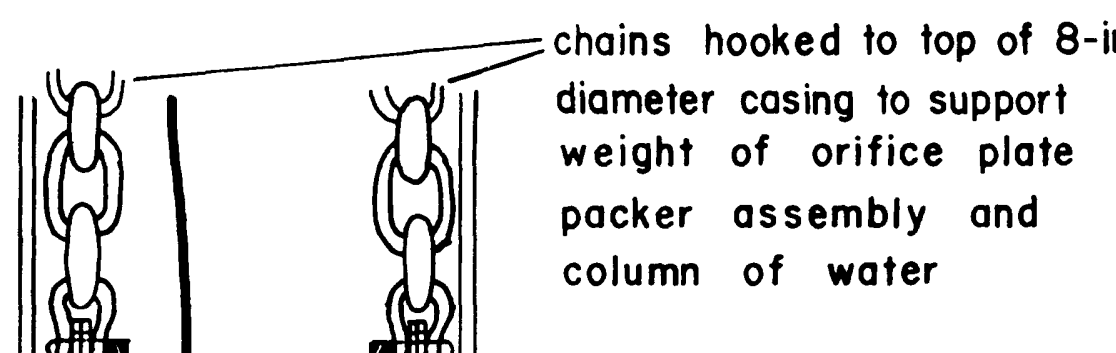

diameter cosing to support

weight of orifice plate packer assembly and column of water

in. $x$ 1/8-in.- thick strap-steel supports /16-in.-thick stainless steel plate with 1.125 -in-diameter orifice 6-in.-diameter threaded PVC cap with center cut out 6-in-diameter threaded PVC coupling 6-in.-diameter PVC slip coupling hose clamps to hold rubber sheath in place short section of 6-indiameter PVC

tube collar pieces of PVC glued to couplings to support inflated tube small inflated tire tube ( shown inflated and in cross section)

rubber sheath (section of truck-tire tube) to protect and hold inflated tube 6-in.-diameter PVC slip coupling

Figure 7. Orifice plate-packer assembly. 


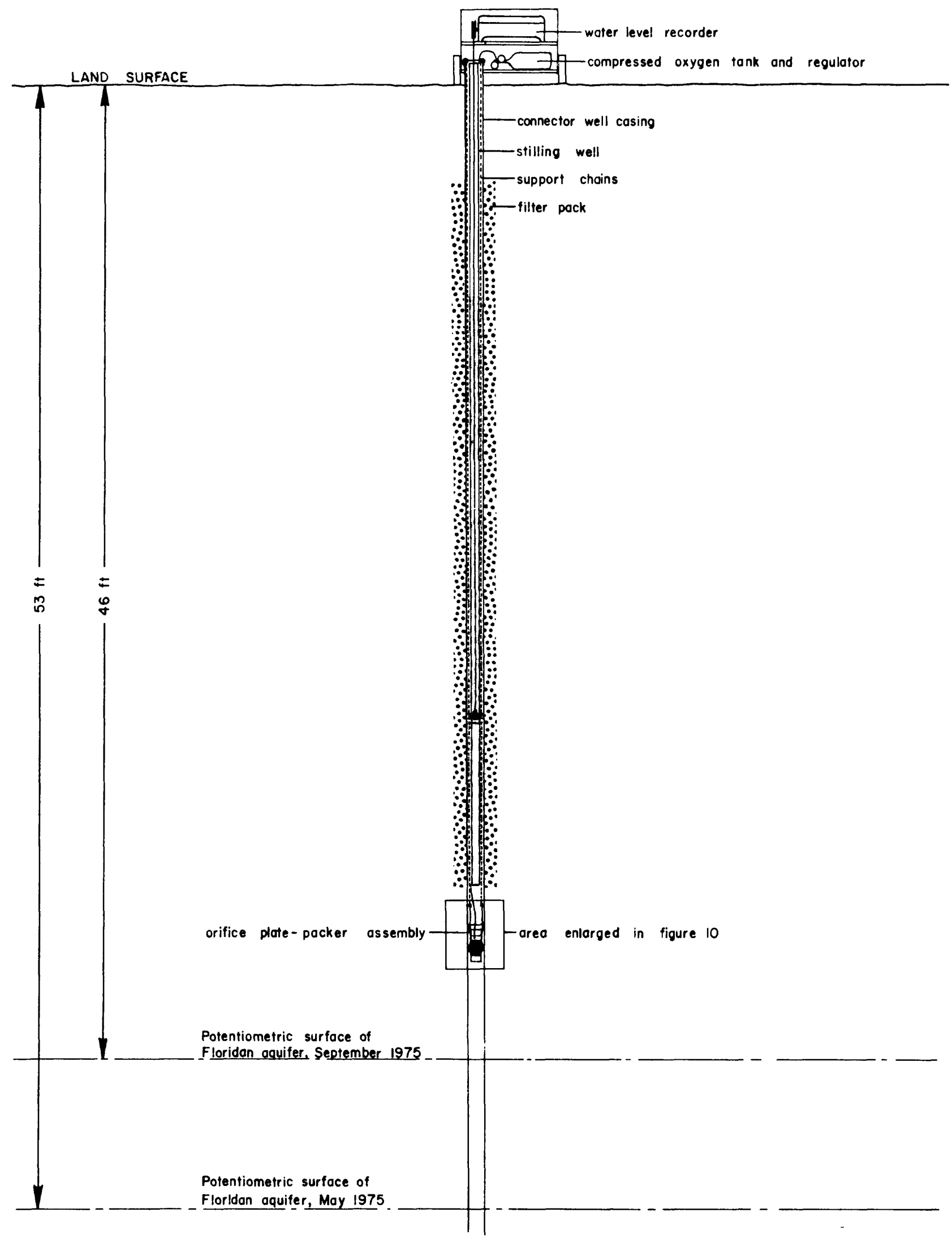

Figure 8. Orifice plate-packer assembly positioned in connector well. 
a vertically positioned 20 -foot section of 8 -inch PVC pipe. Water was pumped through a flow meter into the 8-inch pipe through a 10-foot section of slotted 2-inch PVC pipe inserted in the 8-inch pipe. Water-level (head) measurements for various discharges within the estimated range for the connector well were measured in a stilling well in the 8-inch pipe. A head-versus-discharge rating curve (fig. 9) was developed from that experiment for the 0.06-inchthick stainless-steel plate with a 1.125-inch-diameter orifice in the center. The equation of the line drawn through the points is

$$
Q=16.67 \sqrt{H}
$$

where $Q$ is in gallons per minute and $H$ is in feet. From equations 1 and 2 ,

$$
448.83\left(C_{d} A_{\partial} \sqrt{2 g}\right)=16.67
$$

Thus, the discharge coefficient $\left(C_{d}\right)$ equals 0.67 for the 1.125-inch-diameter orifice.

As indicated in figure 7, the orifice plate can be interchanged easily with another size if necessary by removing the threaded PVC cap that holds it in place. A 1.125inch-diameter orifice was selected by solving equation 2 for $A_{o}$ using reasonable estimates of $Q, C_{d}$, and $H$ for the connector well.

In the case of the east Orange County connector well, the orifice always discharges into air because the potentiometric surface of the Floridan aquifer is well below the plate. If the plate were below the potentiometric surface of the Floridan aquifer, the orifice would be submerged; therefore the head in equation 2 would be the difference between the altitude of the water level above the plate and the altitude of the potentiometric surface of the Floridan aquifer.

The discharge coefficient for submerged orifices is practically the same as for a free jet except that, for heads less than 10 feet and for very small orifices, the discharge coefficient may be slightly less (Daugherty and Ingersoll, 1954 , p. 119). A new rating curve under submerged conditions would be desirable if the plate were to become submerged.

\section{WATER-LEVEL MONITORING}

In all, 31 observation wells were drilled near the connector well in the array shown in figure 10 . The wells are 2-inch-diameter PVC finished with 2-foot sections of slotted PVC screen. The top 5 feet of casing in each well is steel so that the wells will not be damaged by fire. Three lines of wells open at depth 37 to 39 feet (at the depth of the bottom of the connector well screen) extend outward from the connector well to the east, south, and west. A second west line of wells is open at depth 13 to 15 feet, and to the north is a line of wells open at depth 9 to 11 feet. Well 34,10 feet southwest of the connector well, is open 61 to 63 feet below land surface in the confining layer.

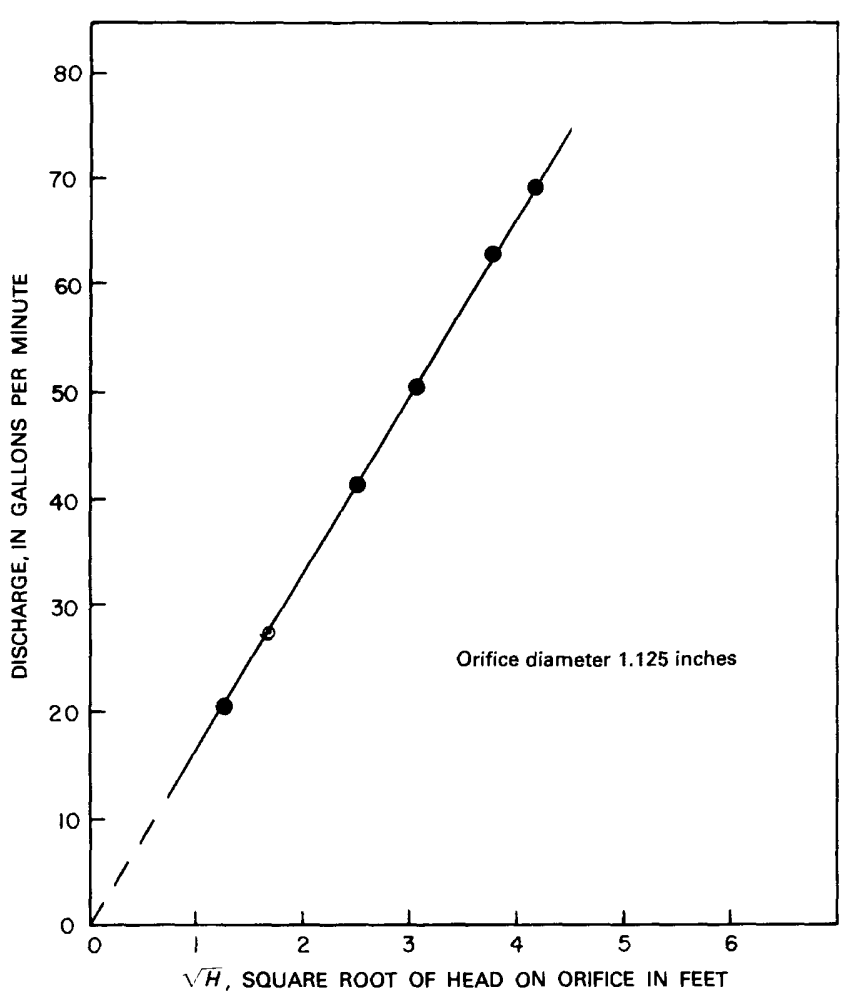

Figure 9. Head-versus-discharge rating curve for 1.125inch orifice.

Water levels are measured in wells 82911101 and 82911102 at site C in SW1/4 sec. 14 (fig. 2). Well 01, 280 feet deep, is open to the Floridan aquifer, and weil 02 is open at depth 37 to 39 feet. Site C, about 0.5 mile from the connector well site, is for practical purposes beyond the area of influence of the connector well.

Although the connector well was completed in October 1974, it was not allowed to flow until November 1975. During the year between connector well completion and opening, background water-level data were recorded continuously at shallow well 03,10 feet from the connector well (fig. 10), and also at the shallow well 02 at site C (fig. 2). Water levels were monitored concurrently in both wells prior to opening the connector well so that a linear regression could be developed for the data. With the regression equation and the record from well 02 at site $\mathrm{C}$, after opening the connector well, estimates could be made of shallow aquifer water levels that would have occurred at the connector well site had the connector well not existed.

Although the altitude of the shallow-aquifer water level at site $C$ averaged about 3.5 feet lower than the unstressed shallow-aquifer water level at the connector well site, the altitude of the potentiometric surface of the Floridan aquifer was virtually the same at both sites. The Floridan aquifer well 01 at site $C$ (fig. 2) was equipped with a recorder to monitor the fluctuation of the potentiometric surface of the Floridan aquifer and, thus, provide a means 


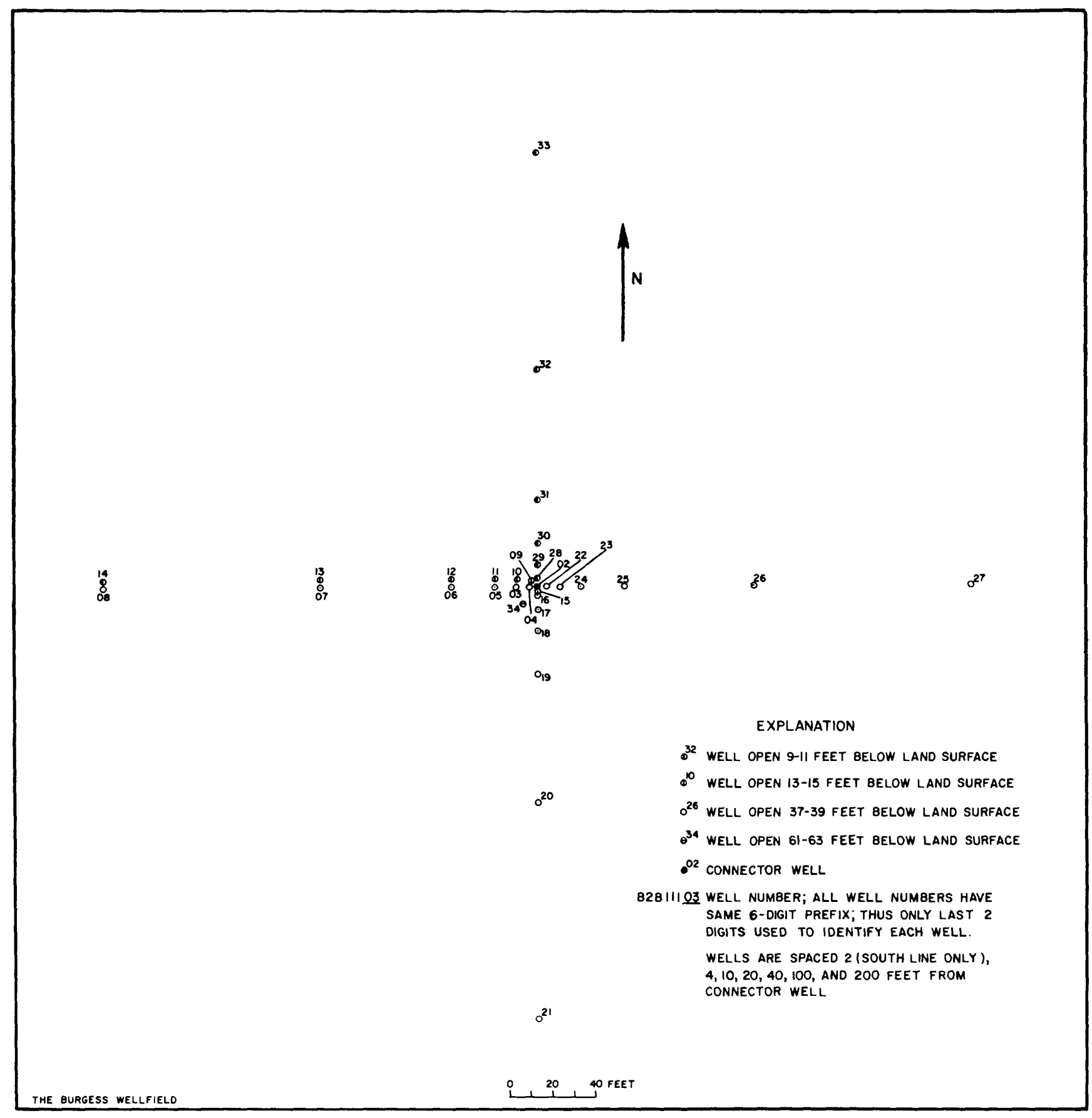

Figure 10. Plan view of observation well network at connector well site. 
of determining whether the orifice plate-packer assembly would remain above that potentiometric surface.

\section{RESULTS OF EXPERIMENT}

\section{Connector well performance}

Actual connector well discharge is very close to preliminary estimates and within the range of calibration of the orifice plate. Connector well discharge was 59 gallons per minute when the orifice plate-packer assembly was installed November 26, 1975, 5 days after the well was opened (fig. 11). Flow declined to a low of 46 gallons per minute in May 1976 and rose to 57 gallons per minute in July and in September 1976.

There was some concern that the screen would clog with ferric hydroxide precipitated from ferrous iron in solution in the ground water when it came in contact with air at the screen. On the basis of a chemical analysis of a sample of water from the test well in SE1/4 sec. 11 (well 82911001 of fig. 2), which contained 1.5 milligrams per liter of iron, the concentration of iron in water in the shallow aquifer in the vicinity of the connector well may be fairly high. Nonetheless, there has not been a noticeable downward trend in flow other than that due to seasonal flow variations. This means that either conditions are not favorable for the precipitation of screen-clogging quantities of iron or the column of water on the orifice plate keeps enough of the screen submerged so that the area of iron precipitation near the fluctuating free water surface in the well is small compared to the length of screen submerged. It is also possible that the precipitation process is very slow and that only after a long period of record, perhaps years, will a decrease in flow be detected.

\section{Water-level response}

When the connector well was opened November 21, 1975, the water level in well 03 at the connector well site dropped about 13 feet almost instantly (fig. 11). It continued to decline at a lesser rate, then rose 2.6 feet on November 26 while the orifice plate-packer assembly was being installed in the well. By the end of January 1976, the shape of the hydrograph of well 03 again resembled the shape of the hydrograph of well 02 at site $C$, which is practically outside the area of influence of the connector well. The shape of the cone of depression on the water table of the shallow aquifer, as measured in the three lines of wells open at the depth of the bottom of the connector well screen, has remained nearly unchanged since shortly after the connector well was opened (fig. 12). Since opening the connector well, shallow-aquifer water levels around the connector well continue to reflect seasonal changes in altitude, but the hydraulic gradient toward the screen does not change very much from month to month. Figures 11 and 12 indicate that, except for the initial stress, most of the change in water levels close to the connector well is due to natural hydrologic stresses rather than stress imposed by the connector well. The cone of depression (at least to a radius of 200 feet from the connector well) reached a nearly steady-state condition in a few days.

Figure 13, a plot of water levels from the lines of wells at 3 different depths (east, south, west lines at depth 37 to 39 feet, west line at depth 13 to 15 feet, north line at depth 9 to 11 feet), shows a considerable vertical hydraulic gradient near the connector well 10 months after opening of the well. This gradient, like the horizontal hydraulic gradient, has been nearly constant since shortly after the well was opened. Some vertical hydraulic gradient would be expected near a well in a water-table sand aquifer due to curvature of the free water surface and flow lines. But the magnitude of the vertical hydraulic gradient is considerably more than would be expected, given the relatively slight drawdown (and therefore slight curvature) of the free water surface measured in the shallowest line of wells. The presupposition that an isotropic, nonartesian sand aquifer exists at the site, with a potential for considerable dewatering, has been discarded.

To try to determine whether thin confining layers that were missed during core samples exist in the shallow aquifer, thus explaining the relatively large vertical gradient, gamma gamma density and neutron porosity logs were run in well 17,10 feet south of the connector well and open at depth 37 to 39 feet. If clay or more tightly packed sand layers were present, differences in density and porosity would be detectable by the logs. No distinct changes in density or porosity due to changes in lithology show on the logs (figs. 14 and 15). A decrease in both density and porosity occurred at the water level in the well (15.7 feet below land surface) and again at the beginning of the saturated zone ( 7.6 feet below land surface measured in well 29, 10 feet north of the connector well and open at depth 9 to 11 feet). An increase in density showed at 4.9 feet below land surface where the casing changed from PVC to steel.

\section{Analysis of results}

To obtain a better understanding and to help in the analysis of the flow system around the well, an equipotential diagram (fig. 16) was constructed from water-level measurements made July 16, 1976. The south line of wells was used to determine equipotentials at the deepest depths, the west line for the middle depths, and the north line for the shallowest depths. No corrections were judged necessary because there is little regional slope on the water table over short distances. Although necessarily idealized because of lack of data, the diagram, without 


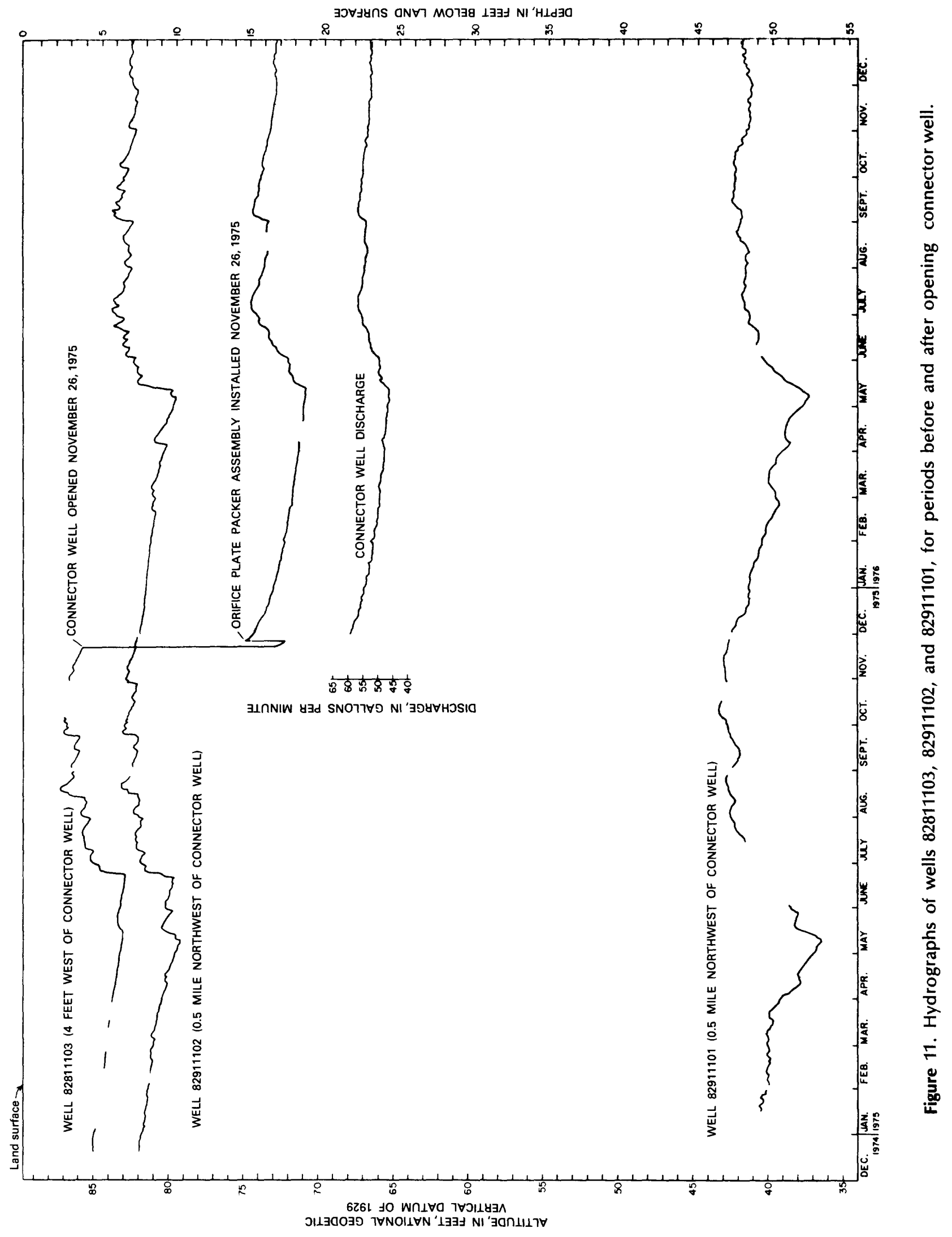




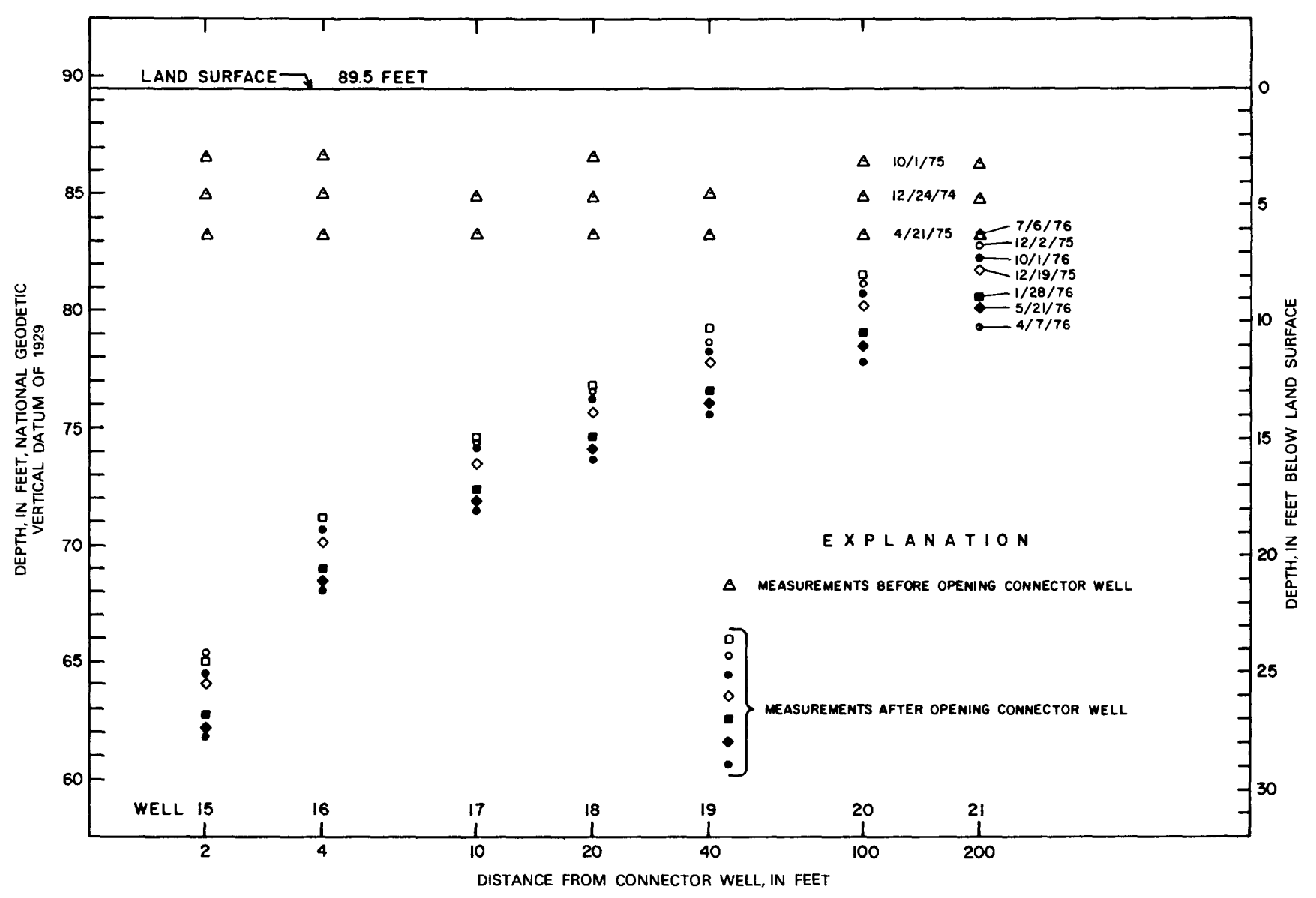

Figure 12. Water levels in observation wells of south line before and after opening connector well.

vertical scale exaggeration, is useful in putting into perspective the steepness of the cone of depression of the free water surface and the effect of the confining layer. Figure 16 shows drawdown in the connector well to be 24.8 feet, while, 4 feet away from the connector well, drawdown of the free water surface is just over 4 feet. The unstressed water-table altitude that would have occurred July 16, 1976, had the connector well not been flowing, necessary to obtain drawdown, was obtained from the regression equation computed from the data of well 03,10 feet west of the connector well, and from well 02 site $\mathrm{C}$ about 0.5 mile northwest of the connector well site.

Dashed lines in figure 16 represent equipotential lines under the unstressed conditions at a time-October 1, 1975-when the water table was approximately equal to the estimated unstressed level that would have occurred July 16, 1976, had the connector well not been flowing. Under unstressed conditions, less than 1 foot of vertical head loss occurs in the $\mathbf{4 0}$ feet of sand comprising the shallow aquifer. About 6 feet of vertical head loss occurs in the first 20 feet of the confining layer. So far as can be determined by water-level measurements, operation of the connector well has not affected water levels in the 62 - foot-deep well (34) that is 10 feet southwest of the connector well and that taps the confining layer. Thus, to conform with water-level measurements, equipotential lines must refract at the shallow aquifer-confining layer interface due to the permeability change.

Figure 17 shows generalized flow lines in the shallow aquifer superimposed on the equipotential lines of figure 16. The flow picture, with flow lines crossing equipotential lines at other than right angles, illustrates the vertical anisotropy of the shallow aquifer. Flow lines perpendicular to equipotential lines are physically unrealistic in this instance because (1) shallow aquifer recharge within the area of influence of the connector well, as defined from a diagram with flow lines perpendicular to equipotential lines, would not be sufficient to maintain connector well discharge and (2) nearly all flow lines would converge just above the confining layer, implying a "pipe" of very high transmissivity there, a physical situation that is known not to exist.

The angles at which the flow lines cross the equipotential lines were constructed with the aid of a permeability ellipse (Liakopoulos, 1965) based on estimates of vertical and horizontal permeability. The estimate for ver- 
tical permeability $\left(K_{v}\right), 0.4$ feet per day, is from laboratory analysis of a shallow aquifer core sample from the test well in SE $1 / 4$ of sec. 11 (well 82911001 on fig. 2). The estimate for horizontal permeability $\left(K_{h}\right), 15.7$ feet per day, is from a transmissivity value of 595 square feet per day calculated from observation well data obtained at the connector well site (discussed on page 23 of this report). While the values used may not be exact, they imply a $K_{h}$. $K_{v}$ ratio of about 39 . For large $K_{h} / K_{v}$ ratios, the angles at which flow lines cross equipotential lines are not particularly sensitive to changes in $K_{h}$ or $K_{v}$. Thus, figure 17 is believed to be a reasonably accurate, but by no means ideal, picture of flow toward the connector well in the shallow aquifer. No attempt was made to construct flow lines in the confining layer because of a lack of permeability and water-level data for that zone.

The most recent (October 1, 1976) water-level data from the connector well site show the drawdown pattern unchanged from the earlier data illustrated in figures 12 and 13. In all probability, the same drawdown configuration, characterized by a relatively small hydraulic gradient of the free water surface toward the well (except very close to the well in the filter pack), together with relatively large vertical hydraulic gradients will continue as long as well discharge continues at about the same rate.

The vertical anisotropy, and hence the predominantly radial flow notwithstanding the relatively large vertical hydraulic gradients, is apparently caused by either the arrangement or shape of the sand grains that comprise the shallow aquifer. The nature and orientation of the grains must be such that water moves much more easily in the horizontal direction than in the vertical. Because of this characteristic of the shallow aquifer, which is probably common throughout east Orange County and perhaps central Florida, extensive dewatering of wetlands by connector wells spaced at thousands of feet probably is not feasible.

Even though extensive shallow-aquifer dewatering by connector wells is unlikely, large amounts of water can be diverted to the Floridan aquifer. Fourteen wells, each discharging 50 gallons per minute, would recharge the Floridan aquifer at about 1 million gallons per day.

The flow situation that the lowermost line of wells "sees" appears to be analogous to that of a leaky confined

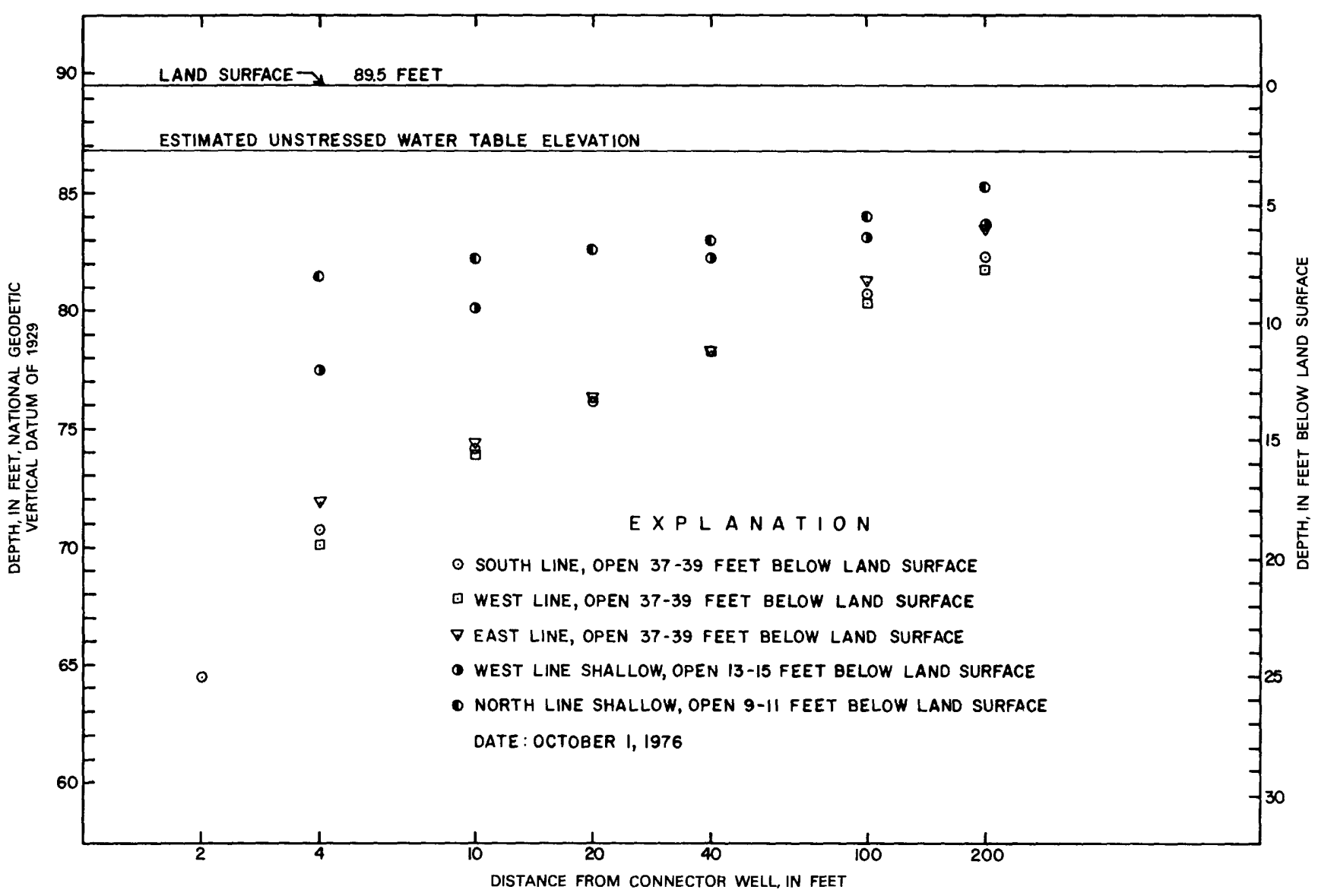

Figure 13. Water levels in wells at three different depths 10 months after opening connector well. 


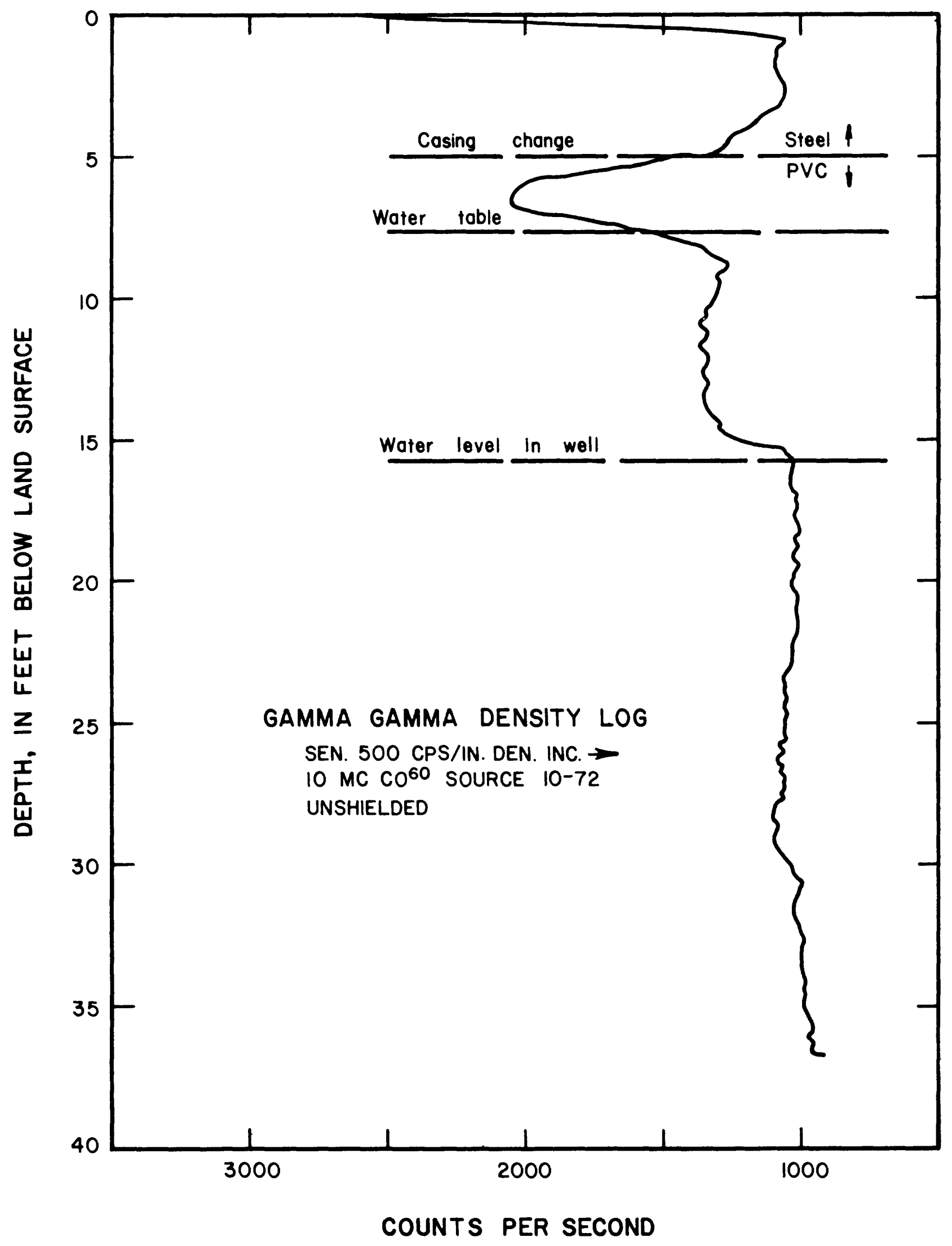

Figure 14. Gamma gamma density log, well 17, August 25, 1976. 


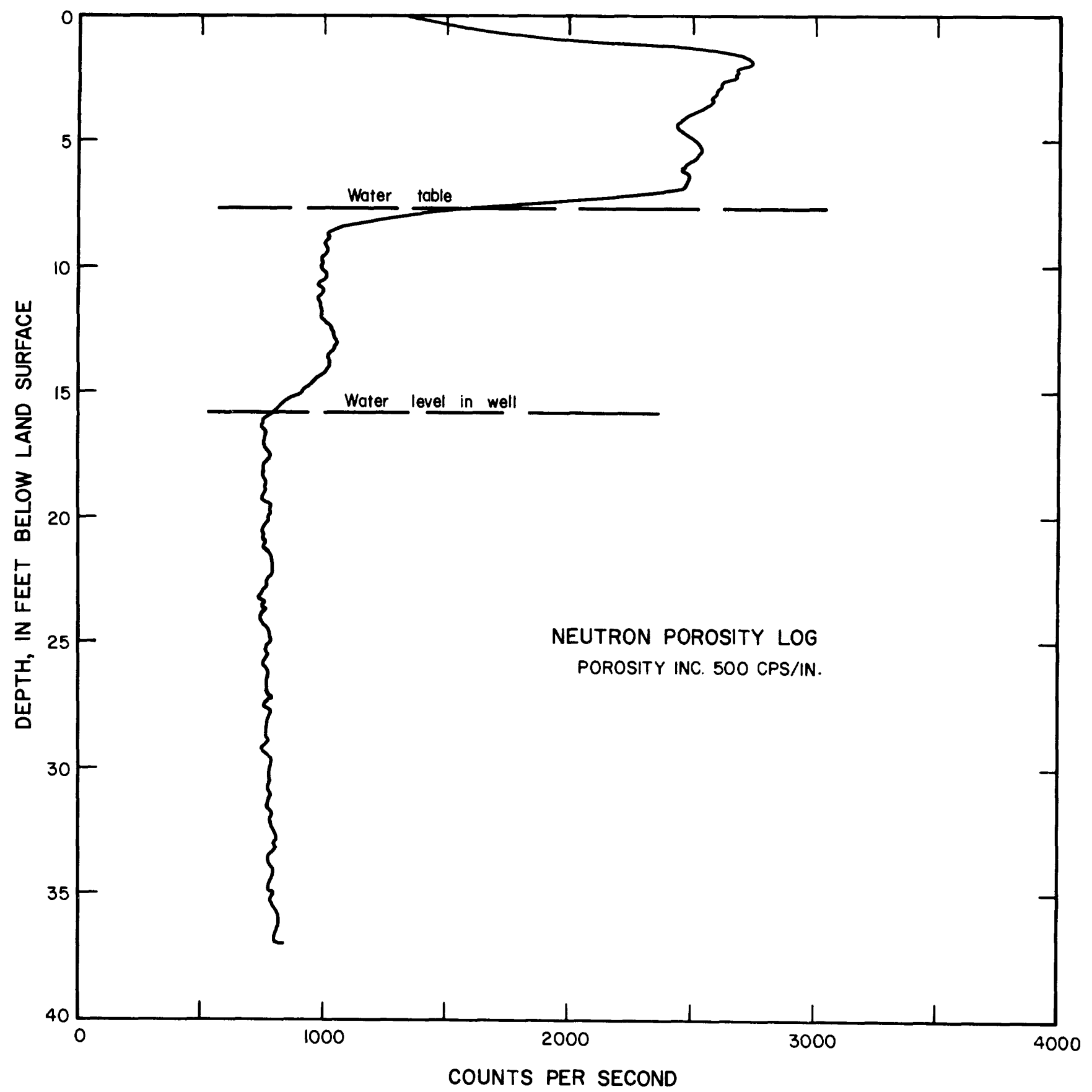

Figure 15. Neutron porosity log, well 17, August 25, 1976.

aquifer stressed by a fully penetrating well. A leaky confined aquifer receives leakage from a constant (on the average) head source across a confining layer as the result of a vertical gradient. The lower part of the shallow aquifer near the connector well receives constant (on the average) recharge from the upper part of the aquifer as the result of a vertical gradient.
Swampy areas, in particular the Wide Cypress Swamp (fig. 2) approximately 2,000 feet west of the connector well, could potentially function as recharge boundaries and thus adversely affect the use of leaky-aquifer theory in this situation. But, as indicated by water levels in wells of the east, south, and west lines (fig. 13), the cone of depression around the connector well is basically 


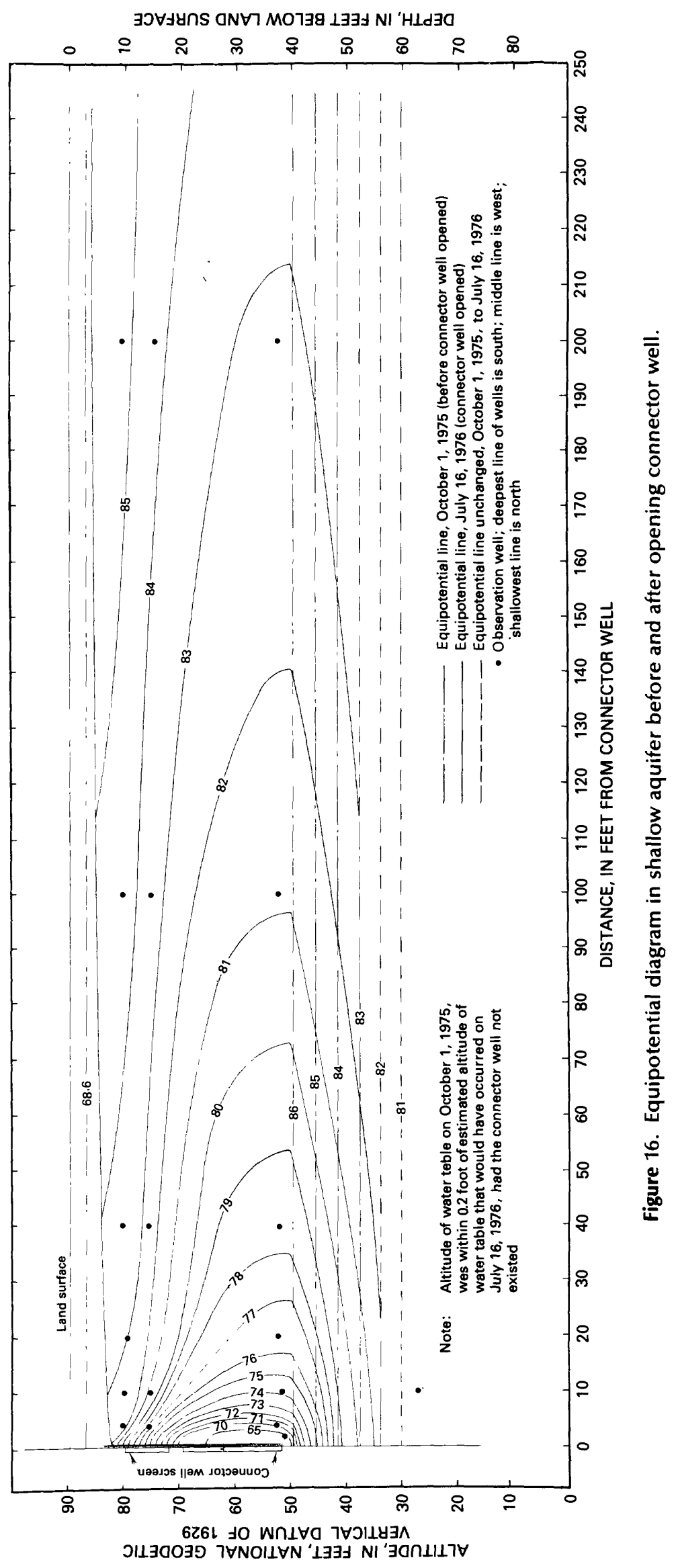




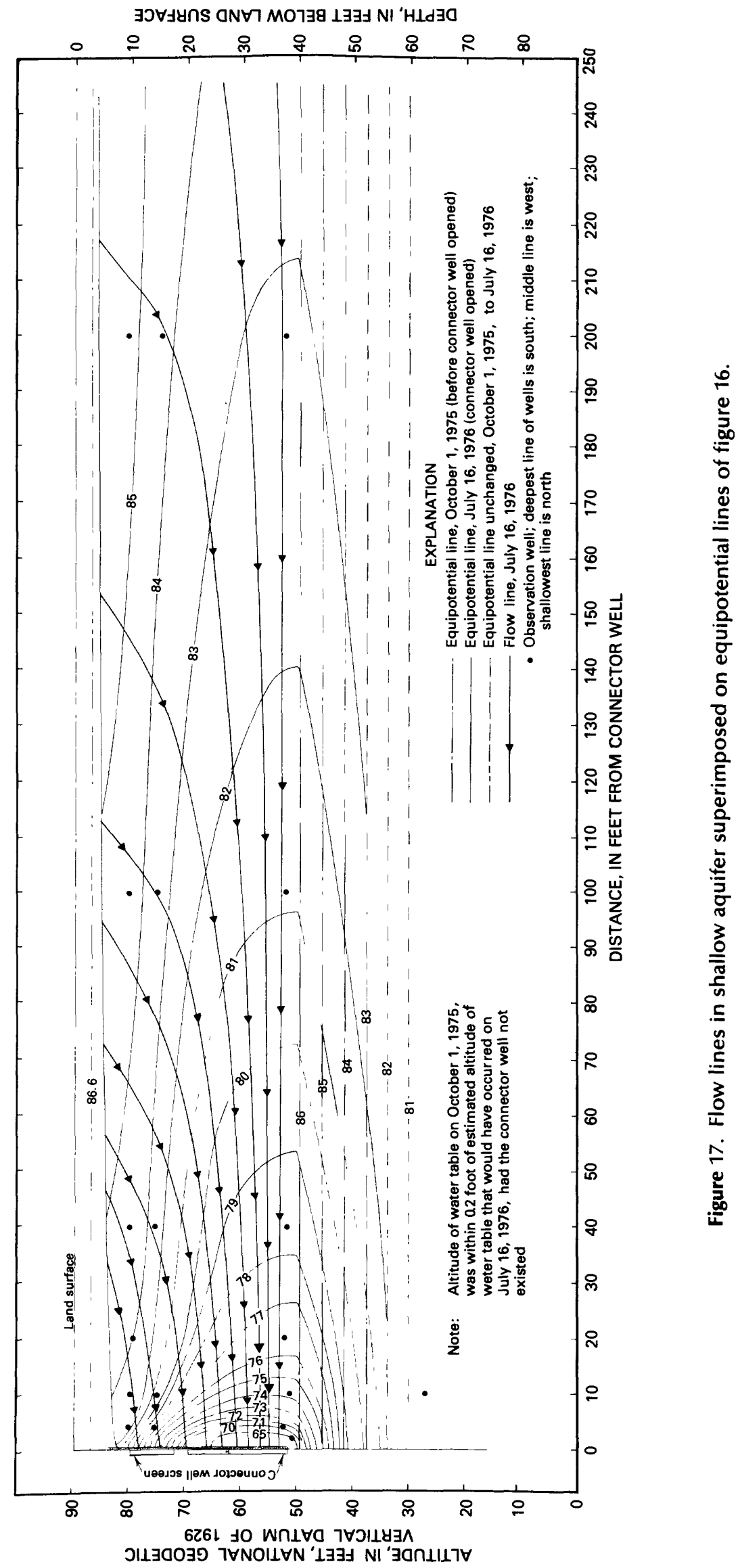


symmetric. The difference among water levels in the three outermost observation wells open 37 to 39 feet below land surface was practically the same in October 1976, 11 months after the connector well was opened, as in October 1975 before the well was opened.

Distance-drawdown data obtained July 16, 1976, 239 days after opening the connector well, are superimposed on the family (and matched to one) of the leaky aquifer type curves prepared by Cooper (in Lohman, 1972, pl. 3A) in figure 18. As shown on the figure, the transmissivity calculated using the match point is 595 square feet per day; the storage coefficient is 0.044 .

Assuming that 0.01 -foot drawdown marks the outer limit of the cone of depression of the connector well, figure 18 can be used also to estimate the radius of influence on July 16, 1976. The estimated radius of influence is 3,100 feet. A recharge rate of 55.9 gallons per minute (the well discharge on July 16, 1976) from a circular area with a radius of 3,100 feet is equivalent to 1.5 inches per year.

An estimate of recharge to the Floridan aquifer from the area of influence also can be calculated by multiplying leakance $(K / b)$, as obtained from the type curve/data match, times the weighted average head difference between the upper and lower parts of the shallow aquifer $(\overline{\Delta H})$ within the area of influence. This result, based on a radius of influence of 3,100 feet, a $\overline{\Delta H}$ of $1.07 \mathrm{feet}$, and a leakance of 6.5 inches per foot per year, is 6.9 inches per year.

The average (areal) recharge rate calculated by dividing the well discharge by an assumed area of influence is considerably less than the recharge rate calculation based on leakance. It is likely that natural gradients near the outer limits of the cone of depression will influence the movement of water in the shallow aquifer at least as much as drawdowns of a few hundredths of a foot there (assuming drawdown at the outer edge of the cone to be 0.01 foot). In 64 percent of the area of such a cone of depression, the drawdown is between 0.1 and 0.01 foot. Theoretically, the expansion of the area within which water is diverted by the operation of such a well continues only until the capture within the area of diversion is equal to the well discharge. Without additional data on the areal distribution of water levels, it is not possible to determine definitely the area inside which water is being diverted to the connector well.

If it is assumed that the drawdown at the outer limit of an "effective" cone of depression is 0.1 foot rather than 0.01 foot, the radius of influence obtained from the type curve/data match for the July 16,1976 , data is 1,890 feet. A recharge rate of 55.9 gallons per minute from a circular area with this radius is 4.2 inches per year. Recharge rate calculated from leakance times weighted average head difference over a radius of influence of 1,890 feet is 7.6 inches per year.

Type curve solutions and calculations similar to those described above were made for data obtained April
7, 1976, May 21, 1976, and October 1, 1976; the results are summarized in table 1 .

Assuming an average annual recharge rate under unstressed conditions at the connector well site to be less than 2 inches per year, an average annual rate greater than 2 inches per year under stressed conditions implies capture. Capture is implied when the recharge rate is calculated based on leakance. If it is assumed that the outer parts of the cone of depression where drawdowns are a few hundredths of a foot contribute insignificant quantities of water to the connector well (because natural gradients there may exert at least as much influence on the direction of subsurface flow), then capture is implied also by a recharge rate calculated by dividing well discharge by an assumed "effective" area of influence.

In the author's judgment, the assumptions are reasonable, and the results of both methods of computing capture imply that capture is occurring within the area of influence of the connector well. However, knowing the actual, effective radius of influence precludes a quantitative definition of capture.

\section{CONCLUSIONS}

1. The shallow aquifer at the connector well site in east Orange County consists of fine sand of uniform size and has a saturated thickness of about 38 feet.

2. The unstressed water table at the site during 1975 ranged from 2 to 6 feet below land surface. The potentiometric surface of the Floridan aquifer at the site during 1975 ranged from 46 to 53 feet below land surface. Thus, the natural head difference at the site varied between 44 and 47 feet.

3. The experimental connector well discharges on the average slightly more than 50 gallons per minute.

4. The screen in the connector well shows no signs of becoming clogged by iron precipitates from the shallow ground water.

5. Except for seasonal variation, water levels within the area of influence of the connector well have, within measurable limits, reached a steady-state condition.

6. Vertical anistropy in the shallow aquifer results in predominantly radial flow toward the connector well, except very close to the well where the free water surface slopes steeply toward the connector well. The vertical anistropy apparently is caused by the shape and (or) arrangement of the sand grains that comprise the shallow aquifer, rather than because of distinct confining layers of different lithology.

7. Calculations of transmissivity of the shallow aquifer at the site yielded values in the range 560 to 600 square feet per day. Storage coefficient calculations resulted in values of 0.01 to 0.04 .

8. Because of the effect of shallow-aquifer vertical anisotropy, extensive dewatering of wetlands in east 


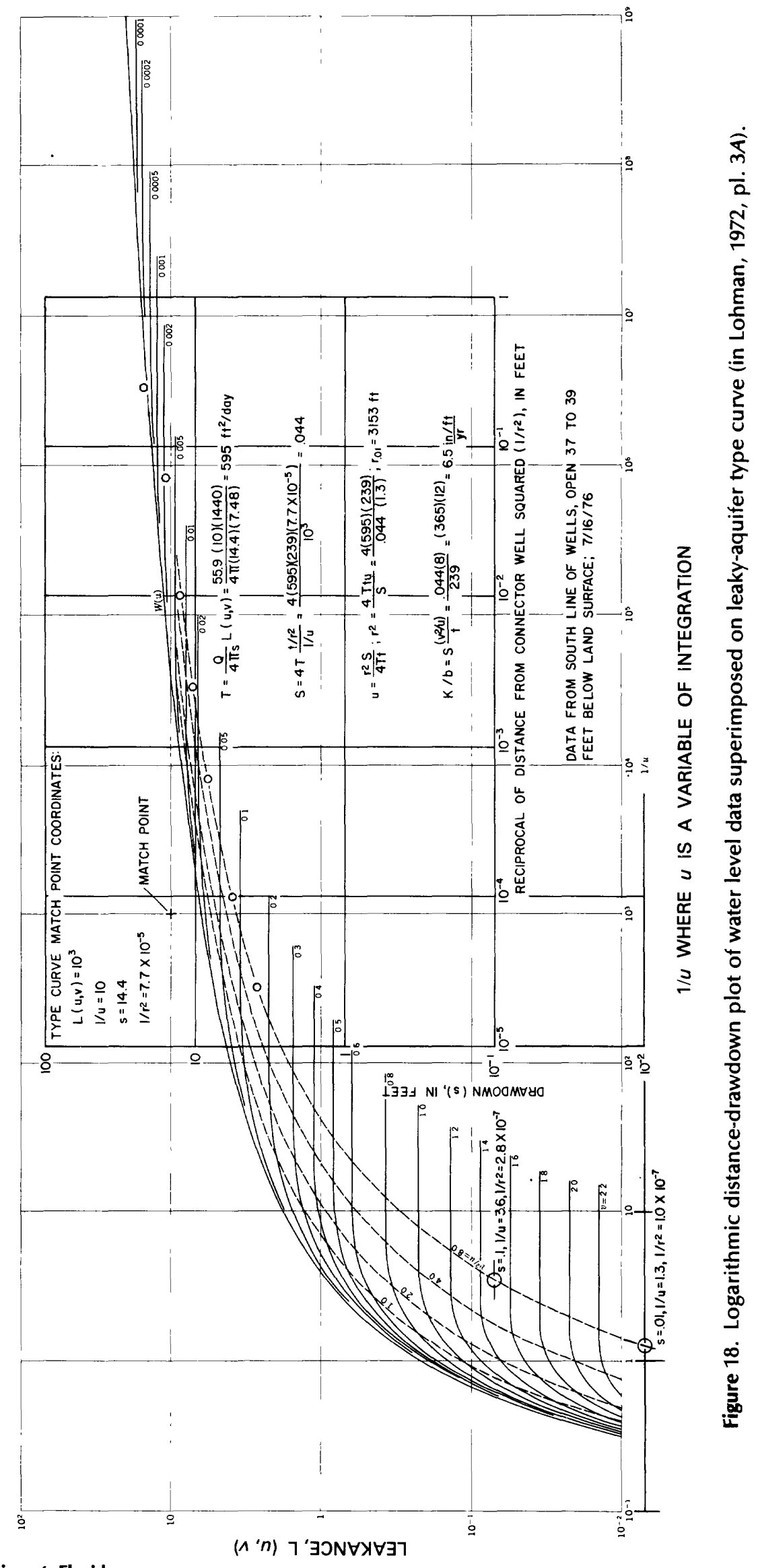


Table 1. Summary of results of type-curve solutions and related calculations

April 7, 1976 May 21, $1976 \quad$ July 16, $1976 \quad$ October 1, 1976

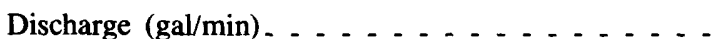

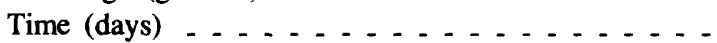

Transmissivity $\left(\mathrm{ft}^{2} / \mathrm{day}\right) \ldots \ldots \ldots \ldots$

Storage coefficient ................

Leakance, $\mathrm{K} / \mathrm{b}((\mathrm{in} / \mathrm{yr}) / \mathrm{ft}) \ldots . . . . . . . . .$.

Radius to point where drawdown is 0.01 (ft) ...

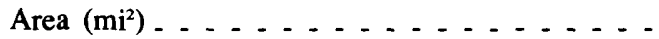

Weighted average head difference, $\overline{\Delta H}(\mathrm{ft}) \ldots$

Recharge, Q/A (in./yr) ............

Recharge, $(\mathrm{K} / \mathrm{b})(\overline{\Delta H})$ (in./yr) . . . . . . . .

Radius to point where drawdown is 0.1 (ft) ....

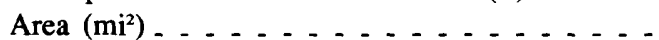

Weighted average head difference, $\overline{\Delta H}(\mathrm{ft}) \ldots$

Recharge, Q/A (in./yr) . . . . . . . . . . . .

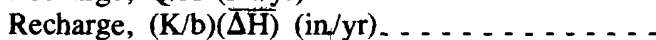

$\begin{array}{cc}48.5 & 48.8 \\ 138 & 182 \\ 595 & 562 \\ .01 & .01 \\ 1.9 & 1.9 \\ 5,883 & 5,756 \\ 3.90 & - \\ -.4 .73 \\ .4 & -.4 \\ -410 & 3,390 \\ 1.31 & 1.30 \\ - & - \\ 1.1 & -\end{array}$

55.9

239

595

.04

3,153

1.12

1.07

1.5

6.9

1,890

.40
1.17

1.17

4.2

7.6
55.3

315

589

.04

4.9

3,602

1.46

1.05

1.1

5.1

2,152

.52

1.14

3.2

5.6
Orange County by connector wells alone probably is not feasible. Nevertheless, large amounts of water could be channeled to the Floridan aquifer by connector wells. Fourteen wells, each discharging 50 gallons per minute, would recharge the Floridan aquifer at about 1 million gallons per day.

9. The results of the connector well experiment imply that water is being captured from evapotranspiration and interception of water that would have discharged to swamps in the vicinity of the connector well. However, the data available from this experiment do not permit a quantitative expression of the net gain in recharge to the Floridan aquifer resulting from the operation of the connector well.

\section{SELECTED REFERENCES}

Cooper, H. H., Jr., 1963, Type curves for nonsteady radial flow in an infinite leaky artesian aquifer, in Bentall, Ray, compiler, Shortcuts and special problems in aquifer tests: U.S. Geological Survey Water-Supply Paper 1545-C, p. C48-C55.

Cooper, H. H., Jr., and Jacob, C. E., 1946, A generalized graphical method for evaluating formation constants and summarizing well-field history: American Geophysical Union Transactions, v. 27, no. 4, p. 526-534.

Daugherty, R. L., and Ingersoll, A. C., 1954, Fluid mechanics: New York, McGraw-Hill, 472 p.

Johnson, A. I., Morton, R. P., and Versaw, S. F., 1966, Laboratory study of aquifer properties and well design for an artificial recharge site: U.S. Geological Survey WaterSupply Paper 1615-H, 42 p.

Knochenmus, D. D., 1975, Hydrologic concepts of artificially recharging the Floridan aquifer in eastern Orange County, Florida-A feasibility study: Florida Department of Natural Resources, Bureau Geology Report of Investigations 72, $36 \mathrm{p}$.

Liakopoulos, A. C., 1965, Variation of the permeability tensor ellipsoid in homogeneous anisotropic soils, in Freeze, R. A., and Witherspoon, P. A., 1967, Theoretical analysis of regional ground-water flow. Effect of water-table configuration and subsurface permeability variation: Water Resources Research, v. 3, no. 2, p. 628-634.

Lichtler, W. F., Anderson, Warren, and Joyner, B. F., 1968, Water resources of Orange County, Florida: Florida Geological Survey Report of Investigations 50, $150 \mathrm{p}$.

Lohman, S. W., 1972, Ground-water hydraulics: U.S. Geological Survey Professional Paper 708, pl. 3A.

Theis, C. V., 1935, The relation between the lowering of the piezometric surface and the rate and duration of discharge of a well using ground-water storage: American Geophysical Union Transactions., v. 16, p. 519-524. 
The inch-pound system of units is used in this report. For readers who prefer the International System of units (SI), the conversion factors for the terms in this report are listed below:

Multiply inch-pound unit

foot (ft)

mile (mi)

square mile $\left(\mathrm{mi}^{2}\right)$

million gallons per day $(\mathrm{Mgal} / \mathrm{d})$

gallon per minute $(\mathrm{gal} / \mathrm{min})$

square foot per day $\left(\mathrm{ft}^{2} / \mathrm{d}\right)$

By

To obtain SI unit

25.4

.3048

1.609

2.590

.04381

.06309

.0929 millimeter (mm)

meter $(\mathrm{m})$

kilometer $(\mathrm{km})$

square kilometer $\left(\mathrm{km}^{2}\right)$

cubic meter per second $\left(\mathrm{m}^{3} / \mathrm{s}\right)$

liter per second $(\mathrm{L} / \mathrm{s})$

square meter per day $\left(\mathrm{m}^{2} / \mathrm{d}\right)$ 